\title{
Re-assessment of lithostratigraphy, biostratigraphy, and volcanic activity of the Late Paleozoic Intra-Sudetic, Krkonoše-Piedmont and Mnichovo Hradiště basins (Czech Republic) based on new U-Pb CA-ID-TIMS ages
}

\author{
STANISLAV OPLUŠTIL, MARK SCHMITZ, VÁCLAV KACHLÍK \& STANISLAV ŠTAMBERG
}

\begin{abstract}
Five U-Pb CA-ID-TIMS high-precision ages were obtained from single zircon crystals separated from tuffs or ignimbrites embedded in Pennsylvanian to Asselian sediments of the Intra-Sudetic, Krkonoše-Piedmont and the adjacent part of the Mnichovo Hradiště basins. The new radioisotopic data are used for extrapolation of ages of dated lithostratigraphic units. The existing borehole network in the Late Paleozoic continental basins of central and western Bohemia and in the Sudetic area, and similarity of their stratigraphically equivalent strata including some common lacustrine horizons allow a detailed lithostratigraphical correlation between these two areas. This in turn, allows combining our new radioisotopic data with similar high precision U-Pb CA-ID-TIMS ages from basins in central and western Bohemia. Result of this correlation is an integrated time-calibrated lithostratigraphical model for the entire Pilsen-Trutnov Basin Complex. This model shows basin-wide alternation of periods of deposition and prevailing non-depostion/erosion due to tectonic events (phases) related possibly from accumulation of stress at plate boundaries. Combined data prove the existence of two new hiatuses; between (1) Duckmantian and Bolsovian and (2) Cantabrian and Barruelian, which have not been previously recognized from the biostratigraphic record. Existing macrofloral and faunal data from these basins were used to assign the lithostratigraphic units to particular biozones and their correlation. In addition, radioisotopic data allowed calibrating these floral as well as terrestrial/fresh-water faunal biozones and their correlation to global stages and thus contribute to integrated and radioisotopically calibrated marine/non-marine biostratigraphy. Four periods of increased volcanic activity have been recognised. Radioisotopic ages of volcanic rocks intercalated in sediments of the basin fill correspond with similar ages of intrusive magmatic activity and demonstrate the relationship between plutonic and volcanic processes. - Key words: Intra-Sudetic Basin, Krkonoše-Piedmont Basin, Mnichovo Hradiště Basin, U-Pb ages, Carboniferous, Permian, Bohemian Massif, volcanism.
\end{abstract}

OPLUŠTIL, S., SCHMITZ, M., KACHLÍK, V. \& ŠTAMBERG, S. 2016. Re-assessment of lithostratigraphy, biostratigraphy, and volcanic activity of the Late Paleozoic Intra-Sudetic, Krkonoše-Piedmont and Mnichovo Hradiště basins (Czech Republic) based on new U-Pb CA-ID-TIMS ages. Bulletin of Geosciences 91(2), 399-432 (14 figures, 2 tables). Czech Geological Survey, Prague. ISSN 1214-1119. Manuscript received January 27, 2016; accepted in revised form June 23, 2016; published online June 30, 2016; issued June 30, 2016.

Stanislav Opluštil (corresponding author) \& Václav Kachlík, Charles University in Prague, Faculty of Science, Albertov 6, 12843 Prague 2, Czech Republic, oplustil@natur.cuni.cz, kachlik@natur.cuni.cz•Mark Schmitz,Department of Geosciences, Boise State University, Boise, Idaho 83725, USA, markschmitz@boisestate.edu • Stanislav Štamberg, Interdisciplinary Research Centre, Faculty of Arts, University Hradec Králové, Rokitanského 62, 50003 Hradec Králové, Czech Republic; s.stamberg@muzeumhk.cz.

The Carboniferous and Permian periods represent one of the most dynamic intervals in Phanerozoic Earth history, characterized by orogenic activity related to assembly of Pangea and by climatic oscillations operating on millennial to multi-million year time scales (Fielding et al. 2008, Birgenheier et al. 2009). These phenomena and processes are recorded in sedimentary basins, the complexity of which becomes increasingly understood as the time resolution of their fill and correlations among basins improve. Most of these correlations are traditionally based on biostratigraphic approaches. However, the strong provincialism of biota in the Carboniferous and Permian makes worldwide correlations on biostratigraphic principles difficult and problems exist even on a continental scale (Davydov et al. 2010). Of particular difficulty is the correlation of marine to non-marine strata because biostratigraphy of both major environments is based on contrasting taxonomic groups (Schneider et al. 2014). To mitigate this problem, 
successions where fossil-bearing marine and continental sediments alternate are intensively studied worldwide to establish integrated marine-terrestrial biostratigraphic charts (Lucas et al. 2011, Schneider et al. 2014). There are other approaches that can improve the correlation at finer resolution, including sequence stratigraphy and cyclostratigraphy. However, even these methods are strongly depending on calibration of individual sequences either biostratigraphically or radioisotopically (Heckel 2002, 2008; Heckel et al. 2007; Davydov et al. 2010; Eros et al. 2012). Moreover, these methods are currently not applicable when correlating marine or paralic successions with those in continental basins.

Recently, the precision of some radioisotopic methods of dating of magmatic minerals has for the first time reached or even exceeded the resolution of most biostratigraphic zonations (e.g. Schmitz in Gradstein et al. 2012). These methods thus provide an alternative approach to testing stratigraphic correlations. Although these data are still relatively rare, where available, they help to calibrate local lithostratigraphic units, identify hiatuses, and via numerical ages correlate local lithostratigraphic units and biozones to Global Chart (e.g. Davydov et al. 2010, Pointon et al. 2012, Schmitz \& Davydov 2012, Michel et al. 2015, Opluštil et al. 2016). Such an approach can be very useful in continental basins, where floral and faunal biozones are difficult to correlate to marine zones and, in turn, to global stages. This is the case of the Intra-Sudetic, Krkonoše-Piedmont and Mnichovo Hradiště basins located in the northern part of the Bohemian Massif, a geological unit formed by amalgamation of several terranes during the Variscan orogeny (Schulmann et al. 2014). Their depositional history ranges from the late Viséan or Asturian, respectively, into the Triassic. Significant portions of the basin fill bear macroflora and palynomorphs as well as vertebrate and invertebrate faunas, which have been systematically collected and studied for nearly two centuries (see Tásler et al. 1979 and Pešek et al. 2001 for overview). The fossil record is crucial for understanding their stratigraphy and depositional history and allows their correlation with other continental or paralic basins in Europe (Cleal et al. 2010, Opluštil et al. 2016). The importance of the Intra-Sudetic, Krkonoše-Piedmont and Mnichovo Hradiště basins is further amplified by the presence of syn-depositional volcanic rocks, which can provide radioisotopically derived ages and stratigraphic reassessment of some local lithostratigraphic units and biozones. In this contribution we provide the results of new $\mathrm{U}-\mathrm{Pb}$ zircon age analyses by chemical abrasion isotope dilution thermal ionization mass spectrometry (CA-ID-TIMS) and discuss their importance for the litho- and bio-stratigraphy of the basins. Improved ranges of lithostratigraphic units are established and the correlation of these basins with similar continental basins in central and western part of the Czech Republic is suggested.

\section{Geological setting and stratigraphy of the Intra-Sudetic, Krkonoše-Piedmont and Mnichovo Hradiště basins}

All these three basins comprise parts (sub-basins) of a larger complex of Late Paleozoic continental basins of the Bohemian Massif (Pešek 2004), a Variscan structure located in the territory of the Czech Republic and neighboring states (Figs 1,3). This belt of extensional basins, here referred as the Pilsen-Trutnov Basin Complex ( $c f$. Cháb et al. 2008), was formed after the major collisional processes, resulting from closure of the Rheic/Rhenohercynian oceanic basins separating Gondwana from Laurussia, ceased (Franke 2000, Matte 2001, Winchester 2002, Kroner \& Romer 2013, Žák et al. 2014). Deposition in these post-orogenic basins was interrupted several times by tectonic phases recorded as hiatuses (Stille 1920, Schulmann et al. 2014). The final structural configuration of the basins, however, is a result of subsequent Saxonian and Alpine movements during Mesozoic and Early Cenozoic times (Zdanowski \& Żakowa 1995, Turnau et al. 2002).

\section{The Intra-Sudetic Basin (ISB)}

This $\sim 1800 \mathrm{~km}^{2}$ large basin is located along the $\mathrm{Czech} / \mathrm{Po}-$ lish border at the eastern end of the Pilsen-Trutnov Basin Complex and at the NE periphery of the Bohemian Massif (Figs 1, 3). It forms a complicated NW-SE elongated syncline structure. The basin was established during middle to early late Viséan time after the main phases of the Variscan Orogeny in the Sudetes terminated (Augustyniak 1970, Marheine et al. 2002, Turnau et al. 2002), and including several hiatuses the deposition continued till the Triassic (Fig. 2). Except a short marine incursion in the Late Viséan, sediments are of purely continental origin, composed of fluvial and lacustrine strata with intercalated but mostly subordinate volcanic bodies including lava flows and pyroclastic rocks (ignimbrites, fall out tuffs). The basin fill thickness is estimated to attain $>4000 \mathrm{~m}$ in its center in Poland and about $3500 \mathrm{~m}$ in the Czech part (Pešek et al. 2001), where it is divided into eight formations (Figs 2, 4). They are briefly characterized below, with their ages retained as determined biostratigraphically, mainly by macroflora (Šetlík 1977; Tásler et al. 1979, 1981; Pešek et al. 2001).

\section{Blażkow Formation}

This oldest unit in the Czech part of the ISB occurs only in the Žaclér area from where it continues northward to Poland. It spans the interval from late Viséan to early Namurian (Fig. 2). It is a $>350 \mathrm{~m}$ thick unit dominated by up to 


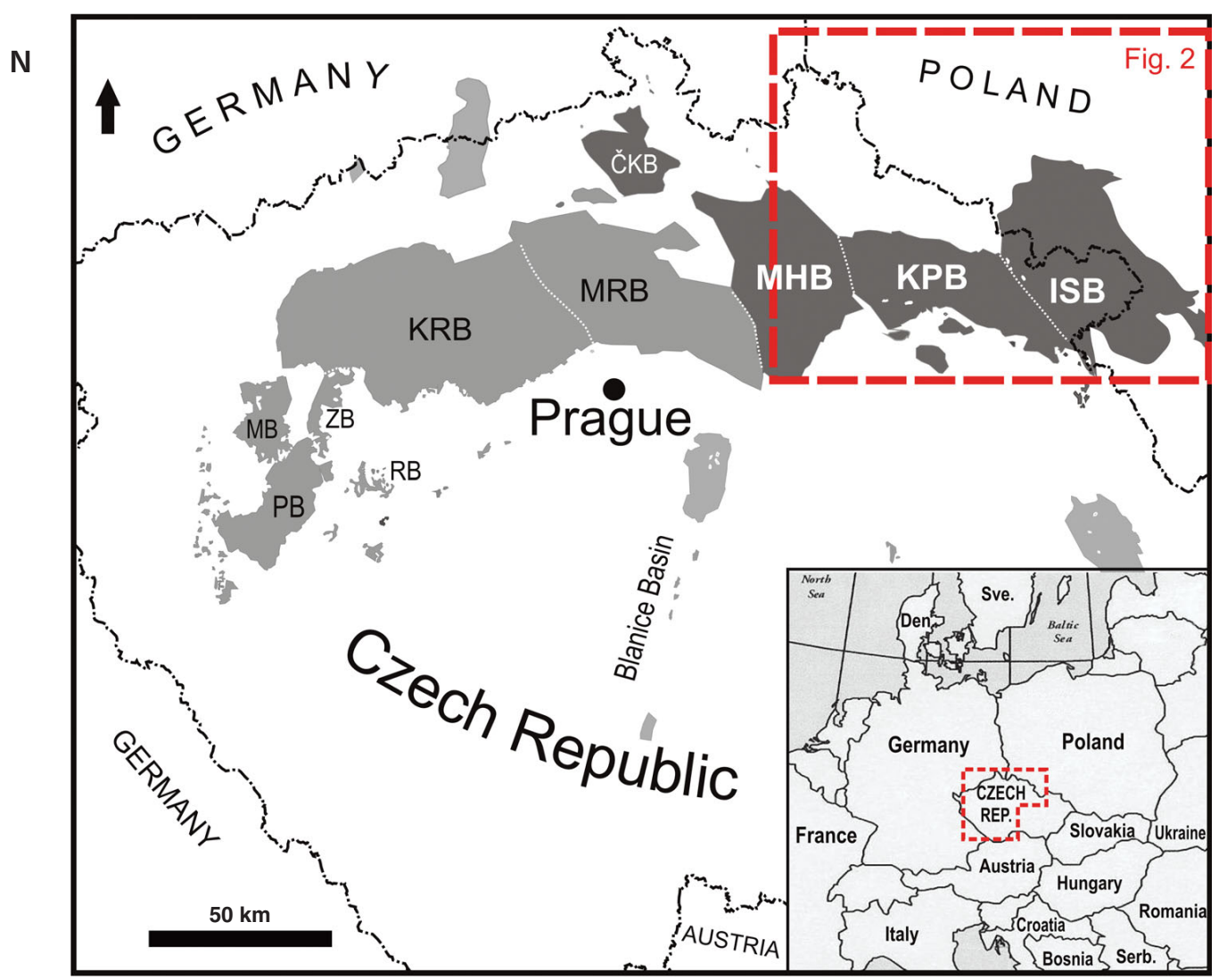

Figure 1. Map of the continental basins of the Czech Republic. Sudetic basins are dark grey, other basins are pale grey. Sudetic basins: ISB - Intra-Sudetic Basin, KPB - Krkonoše-Piedmont Basin, MHB - Mnichovo Hradiště Basin, ČKP - Česká Kamenice Basin. Central and western Bohemian basins: PB - Pilsen Basin, MB - Manětín Basin, ŽB - Žihle Basin, RB - Radnice Basin, KRB - Kladno-Rakovník Basin, MRB - Mšeno-Roudnice Basin.

$80 \%$ of polymict conglomerates. Intercalated subordinate sandstones, greywackes and mudstones are often brownred and usually carbonate (calcite, dolomite, and siderite) cemented (Tásler et al. 1979). Plant fossils are rare in the Czech part of the basin, however Lyginopteris bermudensiformis (Schlotheim) Patt. and Adiantites antiquus Ettingshausen suggest a late Viséan to early Namurian age.

\section{Žacléř (Schatzlar in old German-written literature) Formation}

This formation is an up to $1 \mathrm{~km}$ thick complex of late $\mathrm{Na}$ murian to Bolsovian fluvial sediments dominated by channel facies and divided into the Lampertice, Prkenný Důl-Žd'árky and Petrovice members (Figs 2, 4). The areal extent of the Žaclér Formation significantly exceeds that of the underlying unit, especially in southern part of the basin. Sediments of the formation bear locally up to several tens of coals, some of them reaching economic parameters, except the youngest Petrovice Member, which lacks mineable coals.

The basal Lampertice Member (late Namurian-Duckmantian) reaches a maximum thickness $\sim 700 \mathrm{~m}$ in the Žaclér area close to the Czech/Polish border. South of the
Žaclér̆, however, its thickness decreases to <150 m (Tásler et al. 1979, Spudil 1999). The basal $\sim 100 \mathrm{~m}$ is dominated by conglomerates and coarse-grained sandstones with only few mudstone intercalations. Embedded near Žacléř is a thin basaltic andesite body interpreted as a lava flow (Kaiser 1959) or syn-effusive intrusion (Středa 1972). It is overlain by a several meter thick layer of fine-grained lithic tuff to ignimbrite breccia with admixed sedimentary material in the matrix. In the overlying $600 \mathrm{~m}$, the content of mudstones increases and strata are arranged into coal-bearing cycles between 10 and $15 \mathrm{~m}$ thick (Havlena 1956, Tásler et al. 1979). Coals, which are usually 1 to $2 \mathrm{~m}$ thick, are stratigraphically divided by a conglomerate horizon into lower and upper subgroups. The former comprises 24-28 coals, the latter 32 to 35 coals (Spudil 1999) and together define the Jan Šverma Mine group of coals (Fig. 4). The uppermost 4 coals already belong to the overlying Prkenný Důl-Žd'árky Member (Tásler et al. 1979).

The Lampertice Member contains rich flora which allowed Šetlík (in Tásler et al. 1979) and Purkyňová (1986) to assign the interval between the base of the member up to the level of the lower coal No. 17 to the upper Namurian, the interval between the lower coal No. 16 to the upper coal No. 20 to the Langsettian and remaining upper coals Nos. 19-1 to the 


\begin{tabular}{|c|c|c|c|c|c|c|c|c|c|}
\hline & \multicolumn{4}{|c|}{ Pešek et al. (2001) } & \multicolumn{5}{|c|}{ This study } \\
\hline \multicolumn{3}{|c|}{ TRIASSIC } & \multicolumn{2}{|r|}{ BOHDAŠíN } & \multicolumn{2}{|c|}{ BOHDAŠíN } & \multicolumn{3}{|c|}{ TRIASSIC } \\
\hline \multirow{6}{*}{ 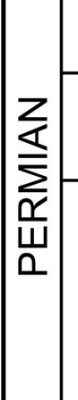 } & & Thuringian & \multicolumn{2}{|c|}{ BOHUSLAVICE } & \multicolumn{2}{|c|}{ BOHUSLAVICE } & \multirow{6}{*}{$\underset{\substack{\alpha \\
\}}{z}$} & \multirow{6}{*}{ 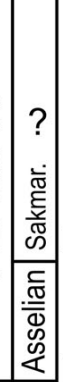 } & \multirow{3}{*}{$\begin{array}{c}\text { Thuringian } \\
? \\
\text { Saxonian } \\
?\end{array}$} \\
\hline & \multicolumn{2}{|r|}{ Saxonian } & \multicolumn{2}{|r|}{ TRUTNOV } & \multicolumn{2}{|c|}{ TRUTNOV } & & & \\
\hline & \multirow{4}{*}{\multicolumn{2}{|c|}{ Autunian }} & \multirow{3}{*}{ 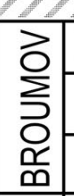 } & Saálé téctonic & \multicolumn{2}{|c|}{ event } & & & \\
\hline & & & & \begin{tabular}{|l|} 
Olivětín \\
\end{tabular} & $\underline{x}$ & Martínkovice & & & $\begin{array}{l}\text { middle to upper } \\
\text { Autunian }\end{array}$ \\
\hline & & & & Nowa Ruda & & Nowa Ruda & & & \\
\hline & & & & Bečkov & I & Bečkov & & & lower Autunian \\
\hline & & Stephan. C & 㐫 & Vernéŕovice & 4 & 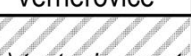 & & 들 & $\begin{array}{l}\text { Stephan. C } \\
\text { Stephan. B }\end{array}$ \\
\hline & 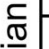 & & & steph & comlar & 7) tecto & & 悹 & Sahorian \\
\hline & 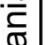 & Stephan. B & & & $>$ & Jívka & & | & Saberian \\
\hline & 등 & Barruelian & 0 & Jivkd & 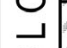 & Asturian tec ev. & & oे & Barruelian \\
\hline os & 心) & & $\overrightarrow{0}$ & & 음 & & $\infty$ & | & Cantabrian \\
\hline Oे & & Cantabrian & a & Svatoňovice & 0 & Svatonovice & O & & Asturian \\
\hline 㐫 & & Asturian & & Asturian teo ev. & Leor & Ian tectonic ev. & 离 & - & \\
\hline Ż & $\frac{\frac{\pi}{\sigma}}{\frac{0}{\sigma}}$ & Bolsovian & & Petrovice & & Petrovice & ○一 & 总 & Bolsovian \\
\hline$\frac{\bar{q}}{\alpha}$ & 용 & Duckmantian & |י & $P D$ - ŽM & | & קי 7 & $\frac{\alpha}{\alpha}$ & & \\
\hline 0 & $\sum$ & & $\overrightarrow{1}$ & & 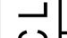 & $r D-\angle I V \mid$ & 0 & - & Duckmantian \\
\hline & & Langsettian & $\mid$\begin{tabular}{c}
0 \\
\hdashline \\
1
\end{tabular} & Lampertice & $\mid$ & am & & 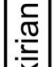 & $\begin{array}{c}? \\
\text { Langsettian }\end{array}$ \\
\hline & . & upper & & & & & & 01 & \\
\hline & $\overrightarrow{\mathrm{E}}$ & middle & & & & 8 & & & \\
\hline & $z$ & er & & & & 1212 & & bे & \\
\hline & & Viséan & & BLAŻKOW & & LAŻKOW & & $\mid$ & \\
\hline
\end{tabular}

lower Duckmantian (Fig. 5). Faunal remnants in the Lampertice Member are rare and include a homoiopterid insect wing, eurypterid and tetrapod footprints (Štamberg \& Zajíc 2008, Turek et al. 2008), all of low stratigraphic value.

The overlying Prkenný Důl-Žd'árky Member (upper Duckmantian) is a unit between 200 and $300 \mathrm{~m}$ thick in average (Pešek 2004). It differs from the underlying member in a higher proportion of conglomerates in the basal part of cycles. Up to about ten seams can be locally present (e.g. Strážkovice group of coals). Where mined, they provided rich flora (Stur 1885-1887), which together with findings from boreholes (Šetlík 1977) indicate an upper Duckmantian age for the member (Fig. 5). Rare fauna is represented by few fragments of blattoid wings (Štamberg \& Zajíc 2008). Volcanic rocks are represented mostly by tonsteins in some coals (Tásler et al. 1979).
Figure 2. Lithostratigraphic units of the Intra-Sudetic Basin and their stratigraphic ranges according to Pešek et al. (2001) and Pešek (2004) compared with subdivision suggested in this paper. Abbreviations: PD-ŽM - Prkenný Důl-Žd'árky Member, $\mathrm{CH}$ - Chvaleč Formation, BR - Broumov Formation, I-W TE - Intra-Westphalian tectonic event.
The youngest and coarsest unit of the formation is the Petrovice Member of upper Duckmantian-Bolsovian age (according to Pešek et al. 2001, Fig. 2) and variable thickness between 50 and $400 \mathrm{~m}$ (Fig. 4). Typical facies along the northern basin margin include the coarse-grained Křenov Conglomerate, which contains cobbles of Cambro-Ordovician metagranitoids and metasediments from the underlying Krkonoše-Jizera Crystalline Complex. Its counterpart along the southern margin is the Hronov Conglomerate, dominated by pebbles of quartz sandstones with Early Paleozoic fossils (trilobites) suggesting possible transport from the Teplá-Barrandian area in the south. These conglomeratic facies are interpreted as alluvial fan deposits and indicate increased tectonic activity during deposition (Tásler et al. 1979). Mudstone intercalations in sediments of the member are subordinate and 


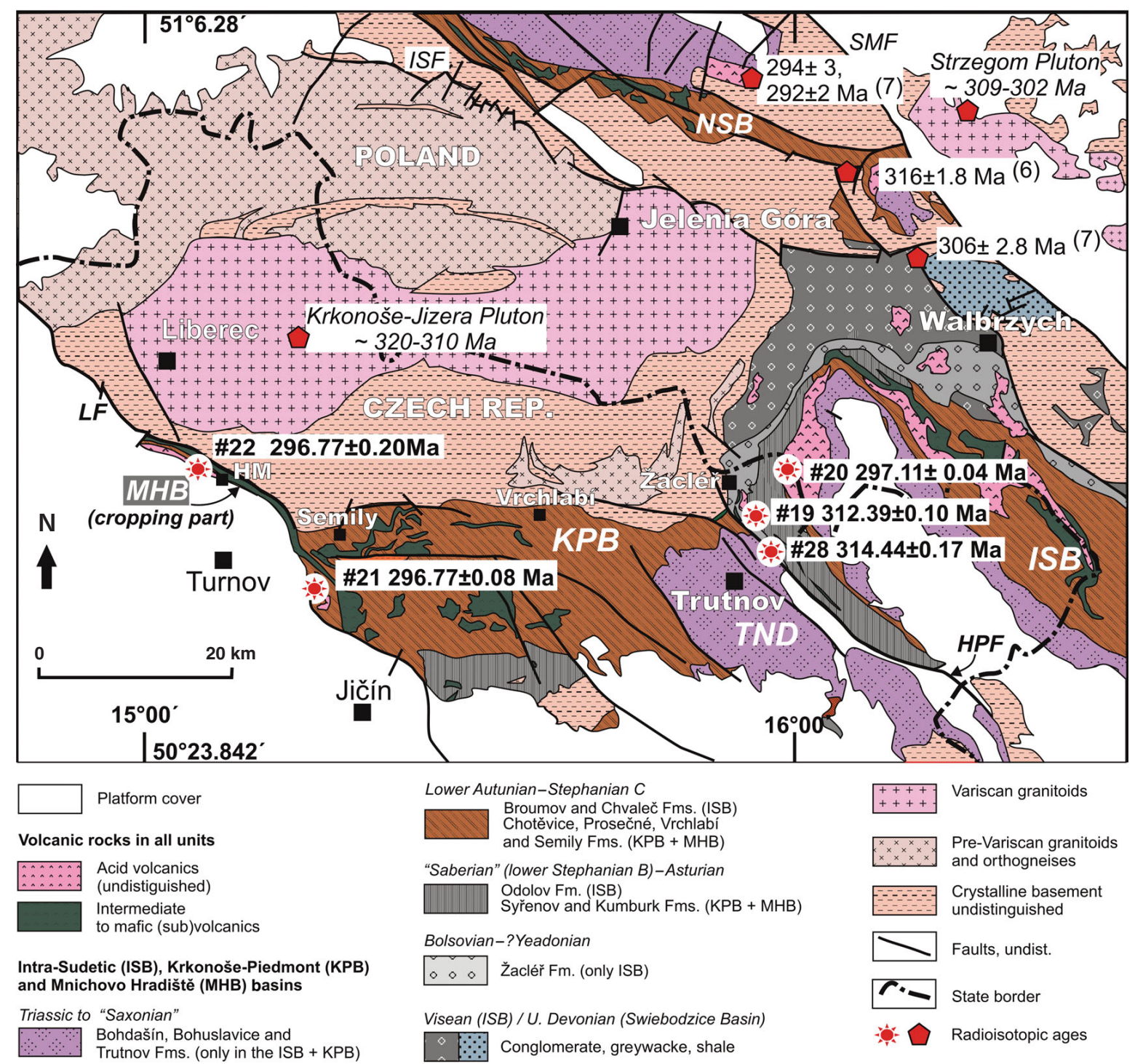

Figure 3. Simplified geological map of the Sudetic area compiled from the geological map 1:500,000 of Cháb et al. (2007) and geological maps of Tásler \& Prouza (1980) and Prouza \& Tásler (1985). Abbreviations: ISB - Intra-Sudetic Basin, KPB - Krkonoše-Piedmont Basin, MHB - Mnichovo Hradiště Basin, TND - Trutnov-Náchod Depression, NSB - North Sudetic Basin, HPF - Hronov-Poříčí Fault, ISF - Intra-Sudetic Fault, LF - Lusatian fault (overthrust), NSB - North Sudetic Basin, SMF - Sudetic Marginal Fault, HM - Hodkovice nad Mohelkou.

most of them are of variegated or red to brown-red color and lack coal. A greater proportion of grey mudstones appear in the upper part of the unit and one of them bears the few decimeters thick Petrovice Coal. Situated $20 \mathrm{~m}$ above the base of the Petrovice Member and exposed in the Babí quarry and the Prkenný Důl and Křenov valleys near Žaclér, are several meter thick subaeric lava flow bodies of basaltic andesite composition rich in vesicles typical of low viscosity flows. Overlying is a several tens of meters thick sequence of coarse-grained polymict conglomerates followed by the Křenov ignimbrite/tuff complex. Its thickness reaches up to $100 \mathrm{~m}$ in the vicinity of Krrenov. North and south the ignimbrite/tuff complex splits into several meters thick crystalloclastic tuff beds some of them being trace- able over a distance of $15 \mathrm{~km}$ (Tásler et al. 1979). Sanidine from this volcanic body provided an ${ }^{40} \mathrm{Ar} /{ }^{39} \mathrm{Ar}$ plateau age of $309.3 \pm 4.6 \mathrm{Ma}$ (Lippolt et al. 1986). Floras of the Petrovice Member are relatively poor compared to underlying coal-bearing units due to unfavorable fossilization potential (Šetlík 1977). Plant species partly overlap with those from the underlying Prkenný Důl-Žd'árky Member, however, Annularia sphenophylloides (Zenker) Gutbier and A. spinulosa Sternberg appear for the first time and indicate a late Bolsovian age (Fig. 5). Fluvial channel facies locally bear silicified stems (Tásler et al. 1979), a mode of fossilization typical for the Late Pennsylvanian part of the basin fill (Opluštil et al. 2013a). Fauna is not known except for the isolated remnant of Arthropleura (Štamberg \& Zajíc 2008). 


\section{Odolov Formation}

This upper Pennsylvanian formation is a complex of mostly fluvial strata of variable lithology and thickness between 400 and $1500 \mathrm{~m}$. Its deposition took place after a biostratigraphically detected hiatus spanning the early "Asturian" (Šetlík 1977). The formation consists of older Svatoňovice and younger Jívka members.

The Svatoňovice Member is a 450-550 m thick unit of late Asturian to Cantabrian age, which is formally subdivided into Lower and Upper Svatoňovice members (Fig. 4). The Lower Svatoňovice Member is an up to $300 \mathrm{~m}$ thick complex of floodplain-dominated fluvial red beds and intercalated lacustrine sediments. It consists of $~ 60 \%$ of mudstones, whereas conglomerates represent only 7 to 15\% (Tásler et al. 1979). Mudstones are dominantly red or red-brown and only very rarely grey. Coal seams are absent. Common are carbonate concretions or beds being mostly pedogenic, the latter of lacustrine origin. In the middle of the Lower Svatoňovice Member there are 3-20 m thick bodies of melaphyre lava flows, alternating with mixed volcano-sedimentary rocks (Holub 1961, Tásler et al. 1979). Plant remains are rare, however, contain several new species, which indicate a late Asturian age of the Lower Svatoňovice Member (Fig. 5). The Upper Svatoňovice Member is up to 180 thick sequence, which differs from the lower part of the member in a higher proportion of channel facies. Present are two coal-bearing intervals, the lower represented by the single Pulkrábek Seam and the upper containing the Cuckovice, Hlavní (Main) and Visutá (Roof) coals, which together with the Pulkrábek Seam comprise the Svatoňovice group of coals (Fig. 4). An argilitized acid tuff (tonstein) was described by Valín (1963) from the Main Coal of the Svatoňovice group. Mudstones of the Upper Svatoňovice Member are grey in proximity of coals, and usually variegated or red between lower and upper coal intervals. Channel facies locally bear silicified woods and red floodplain strata provide mostly poorly preserved shoots of walchian conifers (Tásler et al. 1979). In contrast rich and well-preserved wetland flora accompanies coals of the Svatoňovice group (Fig. 5), suggesting a Cantabrian age of the member (Wagner 1977). Rare fauna includes unidentified conchostracans and fragments of the insect wings and actinopterigian scales.

The Jivka Member is up to $1100 \mathrm{~m}$ thick complex of dominantly fluvial sediments and intercalated subordinate lacustrine facies of Barruelian-Stephanian B age (Šimůnek in Pešek et al. 2001). Its major part consists of up to 800 meters of Žaltman arkoses dominated by feldspar-rich conglomerates and coarse-grained sandstones with only thin intercalations of red mudstone. Typical in channel facies are silicified woods (Mencl et al. 2009 and references herein). In the remaining upper part of the member the content of mudstones significantly increases. Intercalated in these mostly red mudstones (locally with pedogenic carbonate nodules) are three grey intervals bearing coals (Fig. 4). The thickest and most widespread is at the top of the member and bears the Radvanice group of coals. It contains up to 11 coals of which 5 were locally mined and provided rich Stephanian B ("Saberian" in this study) flora (Tásler et al. 1979, Pešek et al. 2001). Rare but relatively varied invertebrates include molluscs, arachnids, blattoid insects, myriapods, and eurypterids (Štamberg \& Zajíc 2008). Volcanic rocks are represented only by a few thin volcaniclastic beds below the top of the Jivka Member, and tonsteins in the $3^{\text {rd }}$ and $5^{\text {th }}$ coals of the Radvanice group (Tásler et al. 1979).

\section{Chvaleč Formation}

In the Czech part of the basin this $\sim 300$ m thick formation is divided into the Vernéřovice (Stephanian C) and Bečkov (probably Autunian) members (Fig. 4), which represent typical "wet" red beds successions (Tásler et al. 1979, Pešek et al. 2001).

The Vernérovice Member is an up to $140 \mathrm{~m}$ thick complex of sediments dominated in its lower half by channel facies. In the upper half of the unit predominating are red floodplain strata with pedogenic carbonates. In the top of the member there are 10-15 m thick horizons of variegated mudstones, marlstones and limestones of the lacustrine Vernéřovice Horizon, bearing ostracods and disarticulated fish remains of low biostratigraphic potential (Pešek et al. 2001). Lateral equivalents of the lacustrine strata include a complex of grey mudstones with the few decimeters thick Rybníček Coal (Fig. 4), which provided late Stephanian C flora (Fig. 5) including poorly preserved callipterids Autunia naumannii (Gutbier) Kerp and Dichophyllum flabellifera (Weiss) Kerp \& Hauboldt (Šetlík in Tásler et al. 1979). Vertebrates include the actinopterygian fish Sphaerolepis kounoviensis Frič, 1877 (Fig. 6) as a typical species of the Stephanian. A thin horizon of volcaniclastic deposit occurs in the Vernérovice Member. Volcanoclastic rock within the Chvaleč Fm. represent less important volcanic activity close to Carboniferous-Permian Boundary ( $1^{\text {st }}$ cycle of Kozlowski 1963).

The Bečkov Member is an up to 200 m thick complex of similar lithology as the Vernéřovice Member below, with bedload-dominated facies in its lower part and predominantly floodplain to lacustrine strata and intercalated

Figure 4. Idealised section of the Intra-Sudetic Basin, its lithostratigraphic subdivision (based on Tásler et al. 1979). Position of regional substages according to Pešek et al. (2001). Stratigraphic location of the dated samples is indicated. 
Stanislav Opluštil et al. • Late Paleozoic Sudetic basins radioisotopically dated

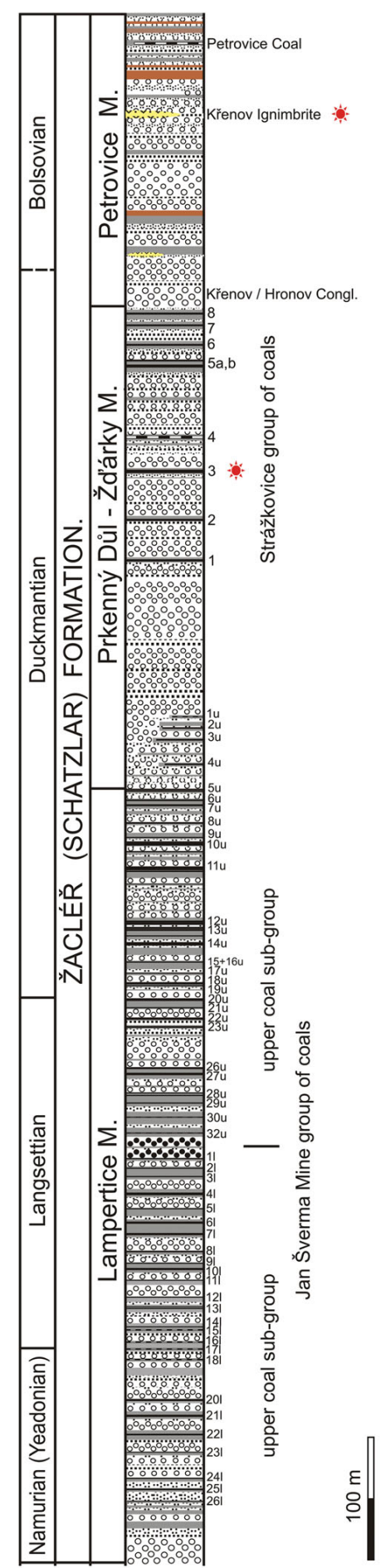

$\because \because 0$ Conglomerate

Conglomerate between lower and upper
$: 0 \%$ coal sub-oroups (Jan Sverma coal group)

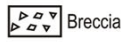

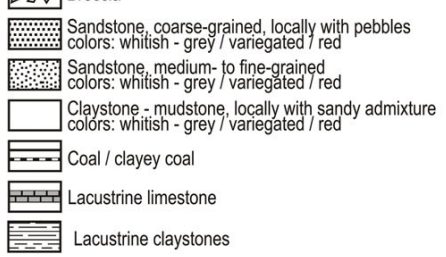

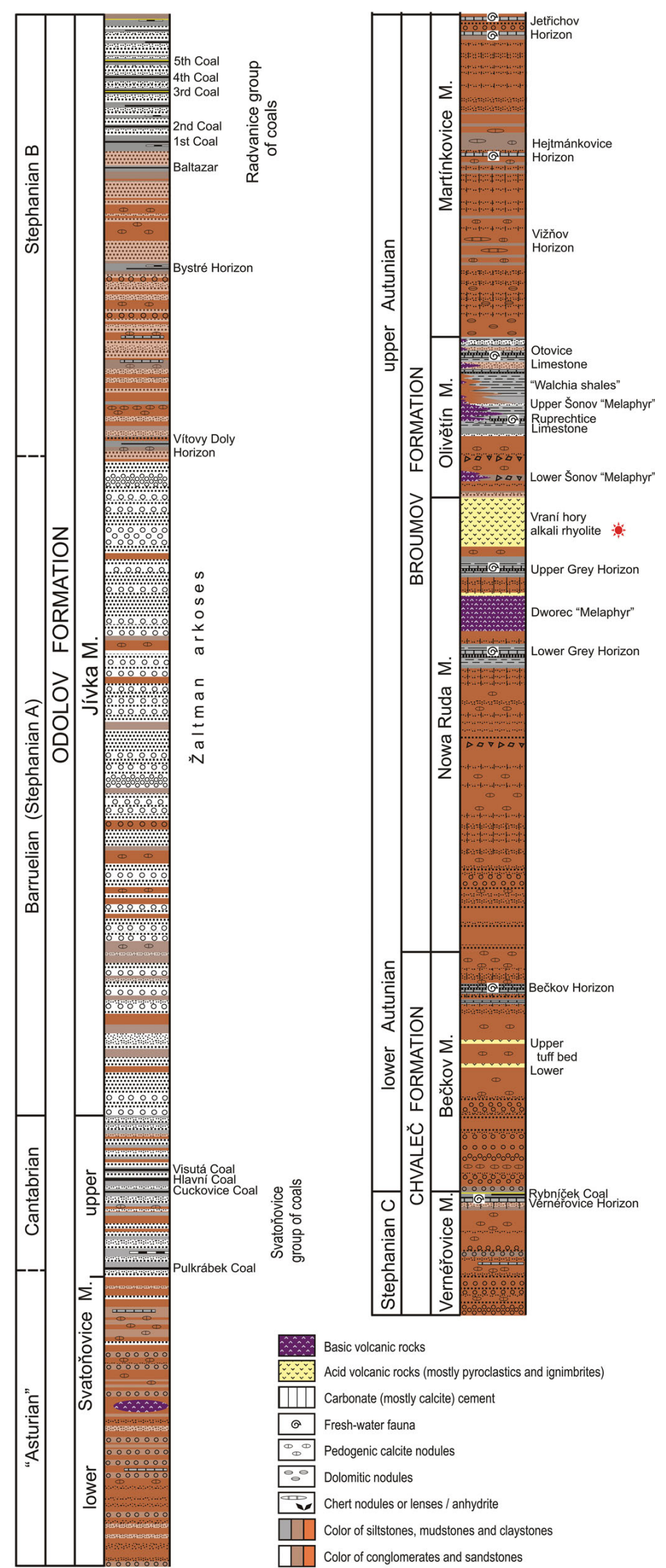




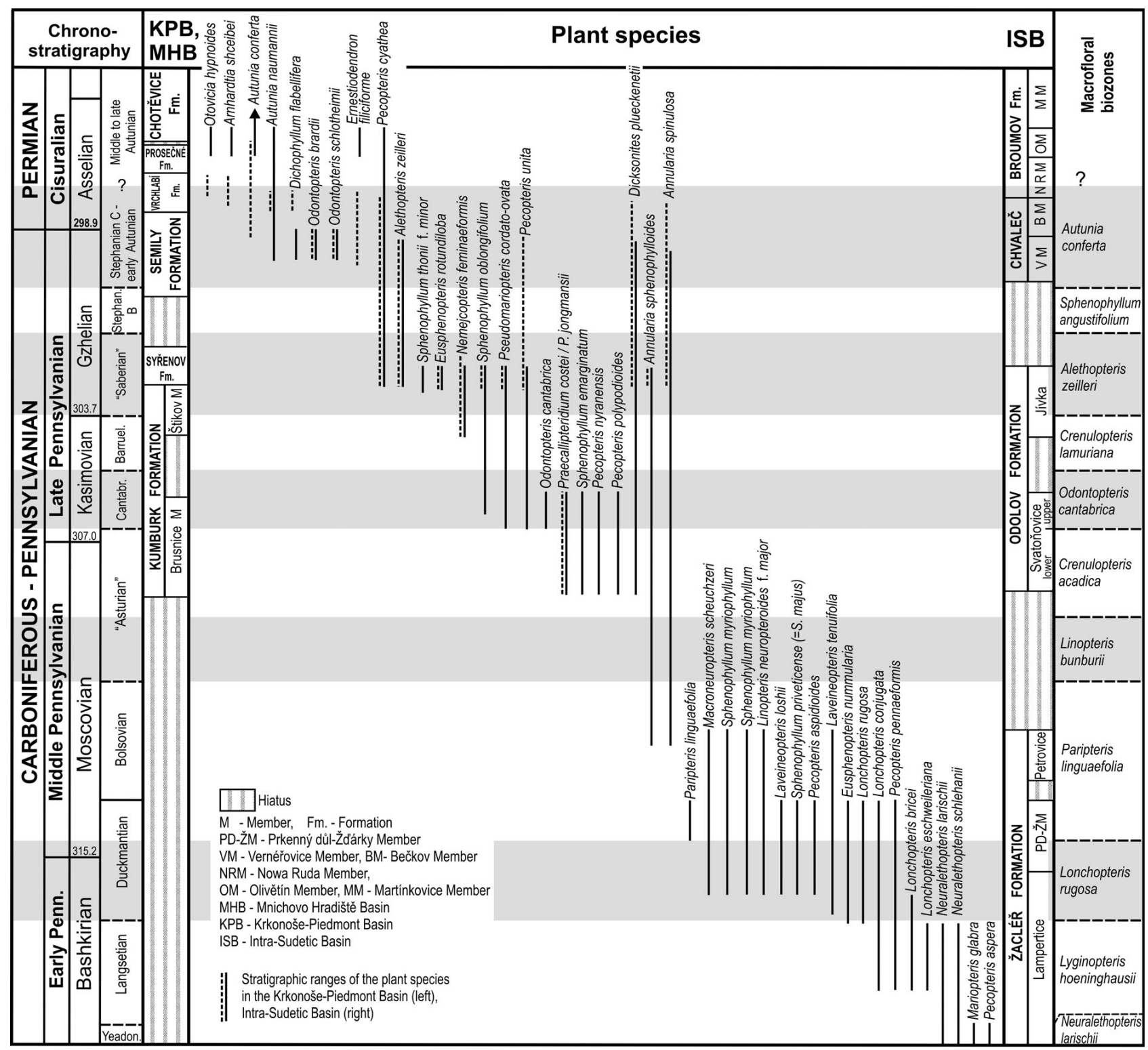

Figure 5. Stratigraphic ranges of selected stratigraphically important plant species in the Intra-Sudetic and Krkonoše-Piedmont basins. According to Pešek et al. (2001), partly modified.

volcaniclastics in its upper part. The lacustrine Bečkov Horizon near top of the member (Fig. 4) is locally $>50 \mathrm{~m}$ thick and besides variegated mudstones bears limestones and bituminous marlstones or claystones (Tásler et al. 1979). Its fossil record is represented by disarticulated fish remains, molluscs and conchostracans Pseudestheria tenella (Bronn, 1850), typical for the early "Autunian" (Pešek et al. 2001).

\section{Broumov Formation}

The Autunian Broumov Formation is a $800-1000$ m thick unit dominated by red mudstones of floodplain and lacus- trine origin (Fig. 4), which comprise about $75 \%$ of the formation thickness. Subordinate are channel facies and intercalated lacustrine carbonates or marlstones. Typical of the Broumov Formation are intermediate to acid volcanic rocks, which locally form up to few hundred meters thick bodies (Tásler et al. 1979). The Broumov Formation is subdivided into the Nowa Ruda, Olivětín and Martínkovice members.

The Nowa Ruda Member is a $400 \mathrm{~m}$ thick succession dominated by red mudstones, siltstones and subordinate fine-grained sandstones. The Lower and Upper Grey lacustrine horizons contain limestone beds and laminated mudstones with poor remnants of walchian conifers and 


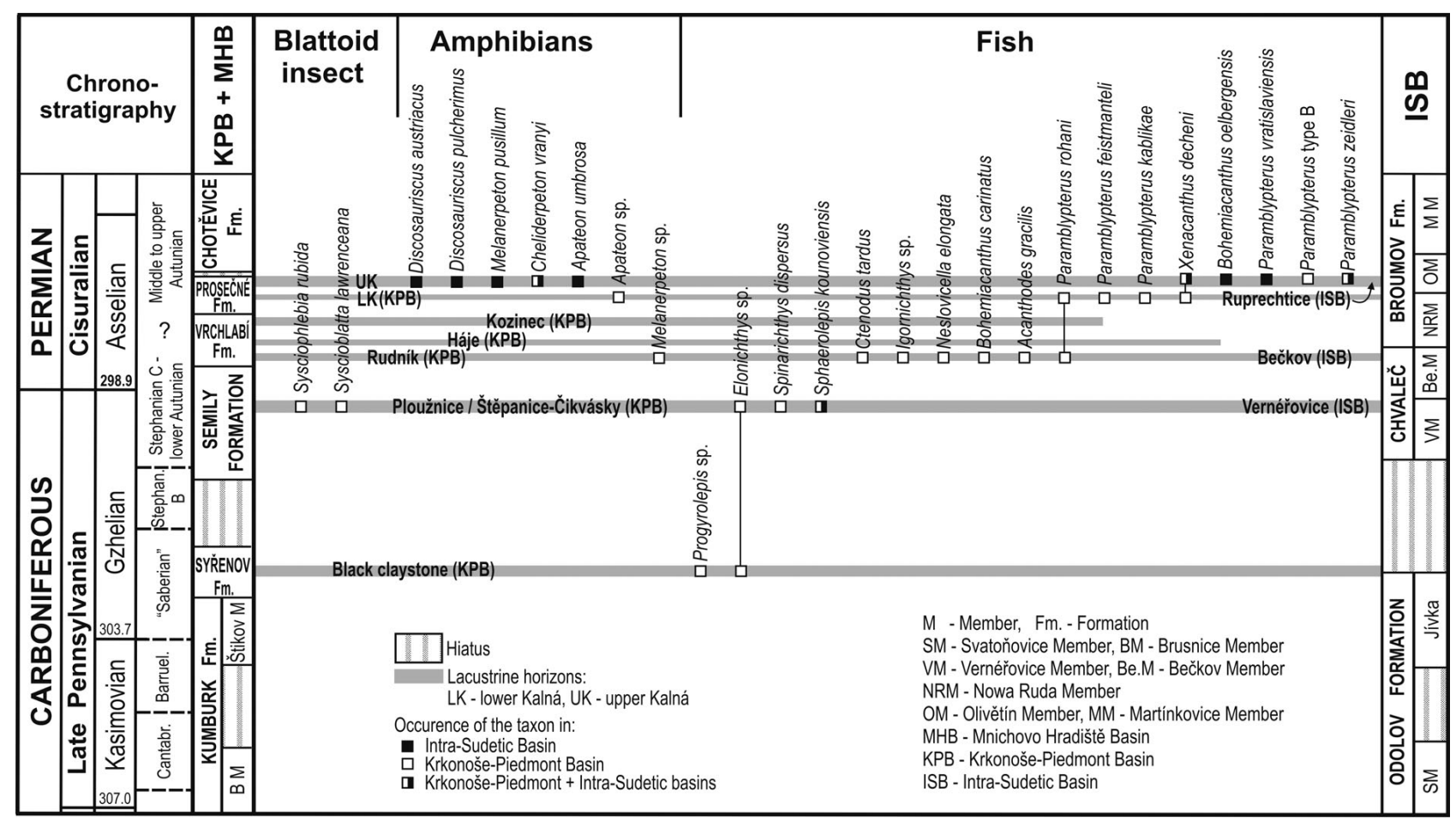

Figure 6. Stratigraphic occurrences of selected fresh-water and terrestrial fauna in the Intra-Sudetic and Krkonoše-Piedmont basins. According to Pešek et al. (2001) and Zajíc (2000, 2007, 2014), partly modified.

callipterids (Šimůnek in Pešek et al. 2001). Where volcanic rocks are present, thickness of the member increases up to $800 \mathrm{~m}$. Basic volcanic rocks are represented by an $\sim 40 \mathrm{~m}$ thick complex of Dworec melaphyres (Fig. 4) composed of several coherent trachyandesite, trachyte and scarce andesite lava bodies. Volcanic rocks in upper part of the member define the 200-300 m high relief of the Vraní and Javoři hory Mountains (Fig. 7A) along the west and east flanks of the basin brachysynform, respectively. The Vraní hory Mts volcanic complex at the base of the member consist of porphyritic alkali rhyolite to rhyolite intruded by a body of trachydacite to trachyandesite composition (Fig. 7B). In the Javoři hory Mts or in the E flank of the brachysynform the upper part of the Nowa Ruda Member is formed by an extensive complex of pyroclastic flows composed of welded and non-welded ignimbrites, bedded air-fall tuffs, pyroclastic surge deposits and mixed volcanoclastic rocks generated by large phreatomagmatic to strombolian types of eruption (e.g. Awdankiewicz et al. 2014).

The Olivětín Member is a $200 \mathrm{~m}$ thick complex of red floodplain and grey lacustrine mudstones, and redeposited or in situ volcaniclastics. The lacustrine strata are concentrated into the several tens of meters thick Ruprechtice and Otovice horizons, composed of grey laminated claystones bearing plant remains including conifers and callipterids. Intercalated limestone beds contain vertebrate and invertebrate faunas (Pešek et al. 2001, Štamberg \& Zajíc 2008,
Štamberg 2013). Invertebrates are represented by pelecypods and conchostracans. The vertebrate fauna is quite diverse (Štamberg \& Zajíc 2008), and comprises chondrichthyan sharks, actinopterygians, discosauriscid and branchiosaurid amphibians including Melanerpeton pusillum (Fig. 6). Schneider \& Werneburg (2012) assigned the Ruprechtice Horizon to their Melanerpeton pusillum-Melanerpeton gracile Zone, which is after the International Chronostratigraphic Chart 2014/02 now interpreted as to be of Sakmarian to Artinskian age (Schneider et al. 2015).

The most important volcanic bodies belong to the Šonov Volcanic Complex, subdivided into Lower and Upper parts by the lacustrine Ruprechtice Horizon (Fig. 4). The Lower Šonov Complex consists of andesite breccias, air-fall tuffs and subordinate mostly vesicular lava flows and acid flows. The Upper Šonov Complex includes various types of pyroclastic rocks of andesite composition (Tásler et al. 1979, Awdankiewicz et al. 2014) and several up to $100 \mathrm{~m}$ thick lava flows of andesitic to basaltoandesitic composition, separated by sedimentary intercalations. The Early Permian volcanic activity is in the ISB terminated by deposition of two $10-15 \mathrm{~m}$ thick layers of kaolinized rhyolite tuffs (Tásler et al. 1979), situated in the upper part of the Olivětín Member.

The Martínkovice Member consists of about $300 \mathrm{~m}$ of red mudstones alternating with subordinate fine-grained 

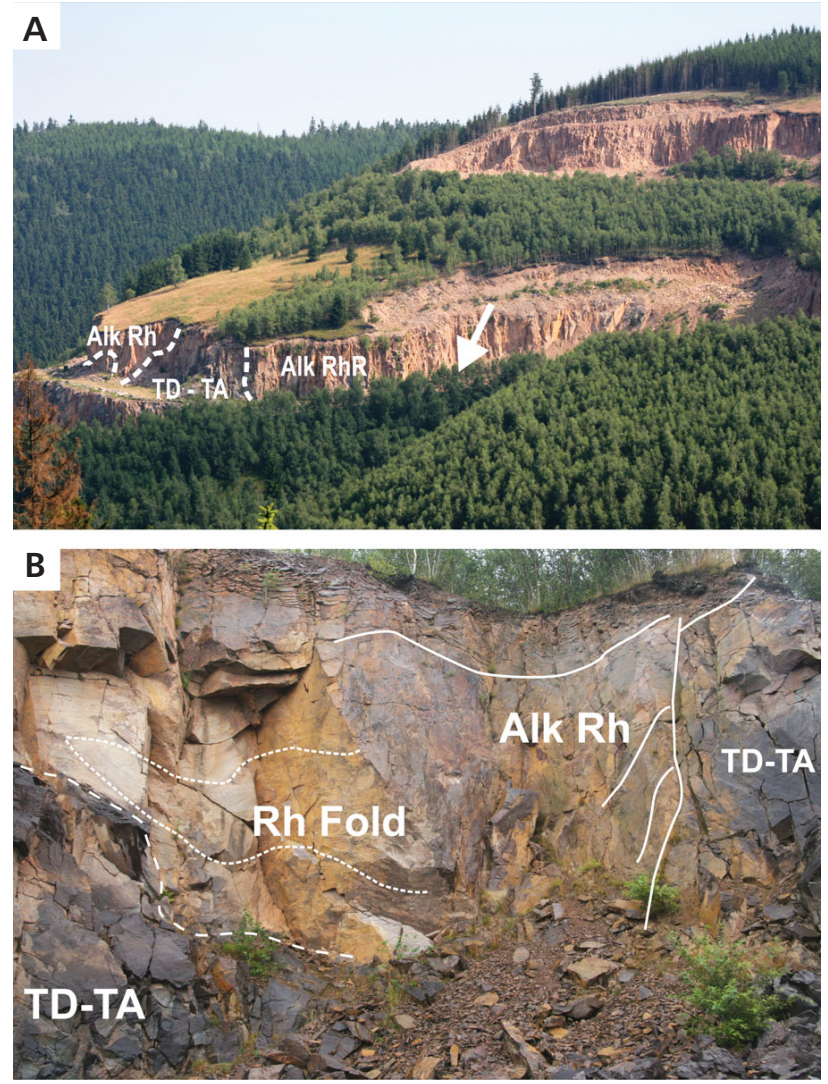

Figure 7. A - view to the north on the quarry $2.85 \mathrm{~km} \mathrm{NNE}$ of Bernartice, western slope of the Vraní hory Mts. Note the darker coeval intrusion of trachydacite to trachyandesite (TD - TA) into the alkali rhyolite (Alk Rh). Quarry walls are $\sim 15-20 \mathrm{~m}$ high. Arrow points to the approximate position of the dated sample. $\bullet \mathrm{B}$ - intrusive contact of trachyte to trachyandesite with alkali rhyolite from the third level of the active quarry near Královec (Vraní hory Mts), Broumov Fm., ISB. The rheomorphic folds and flat magmatic foliation originate in the alkali rhyolite due to vertical shortening during coeval trachyandesite intrusion.

sandstones. Intercalated are several tens of meters thick lacustrine sediments (Fig. 4). The oldest lacustrine Vižňov Horizon consists of variegated mudstones to claystones and beds of red cherts (Tásler et al. 1979). The stratigraphically younger Hejtmánkovice and Jetřichov lacustrine horizons contain less chert but more limestone beds, some of them up to $1.5 \mathrm{~m}$ thick. Flora and fauna are poor and refer only for the Autunian age (Figs 5, 6).

Deposition of the overlying Trutnov, Bohuslavice and Bohdašín formations took place after a hiatus related to the Saale tectonic event (Tásler et al. 1979). These formations lack any fossil record or volcanic rocks and their Saxonian to Triassic age is inferred only from their superposition and correlation to lithologically similar but biostratigraphically-constrained successions in Poland (Pešek et al. 2001). Our new radioisotopic data do not affect the current ideas about their stratigraphic position and therefore these formations remain beyond the scope of this article.

\section{The Krkonoše-Piedmont (KPB) and Mnichovo Hradiště (MHB) basins}

The Krkonoše-Piedmont is $\sim 1100 \mathrm{~km}^{2}$ large W-E elongated basin located on the Krkonoše-Jizera and Orlice-Sněžník crystalline complexes. The NW-SE striking Hronov-Poříčí Fault separates this basin from the ISB to the east (Fig. 3). Its western margin is marked by the Lusatian Fault, which is a part of the prominent NW-trending Elbe fault system (e.g. Arthaud \& Matte 1977, Wenzel et al. 1993, Linnemann \& Schauer 1999, Scheck et al. 2002, Hoffmann et al. 2009, Coubal et al. 2014). The Lusation Fault separates the KPB from the MHB situated west of it. The latter is about $1250 \mathrm{~km}^{2}$ large basin nearly completely concealed by Cretaceous strata and cropping out only along the Lusatian Fault (Fig. 3). Deposition in these basins began in the late Asturian and lasted till the late Autunian times (Figs 8, 9). The Saale tectonic event interrupted the deposition and formed a new NW-SE striking and tectonically bounded depocenter along eastern margin of the KPB (Pešek et al. 2001). This Trutnov-Náchod Depression bears in stratigraphic order sediments of the Trutnov, Bohuslavice and Bohdašín formations present also in the Intra-Sudetic Basin. However, we do not deal with them because our radioisotopic data do not affect their chronostratigraphic interpretation. Briefly characterized here are only the six older, pre-Saale formations that are common for both basins (Figs 8, 9).

\section{Kumburk Formation}

This oldest formation is a complex of fluvial red beds locally with pedogenic carbonate nodules in red mudstones overlaying the Variscan basement. The formation reaches a maximum thickness of $\sim 600 \mathrm{~m}$ in the southern half of the basin, where it is divided into the Brusnice and Śtikov members (Figs 8, 9).

The Brusnice Member is a 150-170 m thick complex composed of red mudstones or subordinate fine-grained sandstones which alternate with up to a few meters thick channel sandstones and conglomerates. Proportions of floodplain and channel facies vary throughout the section; the lower part is richer in channel facies and upper in floodplain deposits. In grey-green mudstones intercalated in the overall red floodplain-dominating upper part of the succession. Rieger (1968) found plant remains including Praecallipteridium costei (Zeiller) Wagner, typical for the Svatoňovice group of coals of the Intra-Sudetic Basin (Šetlík 1977). It suggests an Upper Asturian to Cantabrian age for the member. The volcanic rocks are rare, represented by small intrusive stocks or feeding channels near Pecka and elsewhere.

The Štikov Member is about $340 \mathrm{~m}$ thick succession of Barruelian age (Fig. 9) dominated by pinkish coarse- 
grained arkoses and subordinate conglomerates and red mudstones. The unit is considered as a lithological and stratigraphical equivalent of the Žaltman Arkoses of the ISB. Besides the common silicified woods, no other fossil remains have been found in the Štikov Member.

\section{Syřenov Formation}

The Syřenov Formation reaches a maximum thickness of $\sim 120 \mathrm{~m}$ in the southern part of the basin and it is absent along its northern margin. The lower part of the formation has a cyclic pattern of strata with coarse-grained arkoses at the base of cycles. Four of these cycles bear coals, which together comprise the Syřenov group of coals, an equivalent of the Radvanice group of coals in the ISB (Fig. 8). Both contain very similar flora including Alethopteris zeilleri (Wagner ex Jongmans) Wagner, A. bohemica Franke, and Odontopteris nemejcii (Němejc) Šimůnek \& Cleal (Fig. 5). Above is a several tens of meters thick complex of arkosic sandstones. The upper part of the formation starts with variegated mudstones and intercalated tuff beds followed by 13-23 m of laminated claystones of the lacustrine Black Claystone Horizon. This horizon contains fish remains including scales of Elonichthys sp. and Progyrolepis sp. (Fig. 6), and it is considered as a stratigraphic equivalent of the lithologically identical lacustrine Mšec claystones in basins of central and western Bohemia (Skoček 1990, Pešek 1994, Pešek et al. 2001). Above the Black Claystones there are grey to greenish mudstones alternating with thin beds of siltstones and/or fine-grained sandstones. This uppermost part of the Syřenov Formation is correlated with the Hředle Member in the basins of central and western Bohemia (Havlena \& Pešek 1980). Flora and fauna of the formation suggest its Stephanian B age (Pešek et al. 2001). Volcaniclastics are represented by only a few thin tuff beds in some coals of the Syřenov group and in the overlying lacustrine horizon of the Black Claystones.

\section{Semily Formation}

The Semily Formation is a 300-500 m thick complex of fluvial red beds separated from the underlying Syřenov Formation by a biostratigraphically apparent hiatus (Figs 8, 9). The formation is characterized by an alternation of coarse-grained sandstones and polymict conglomerates with red fine-grained sandstones, siltstones and mudstones (Pešek 2004). Subordinate, but stratigraphically important, are lacustrine strata of the Štěpanice-Čikvásky and Ploužnice horizons. The Štěpanice-Čikvásky Horizon along the northern basin margin consists of two lacustrine intervals of grey to green mudstones each 5 to $40 \mathrm{~m}$ thick and separated by several tens of meters thick fluvial red beds. Both intervals contain locally mineable coals associated with bituminous claystones with fish scales (Havlena 1957). Its

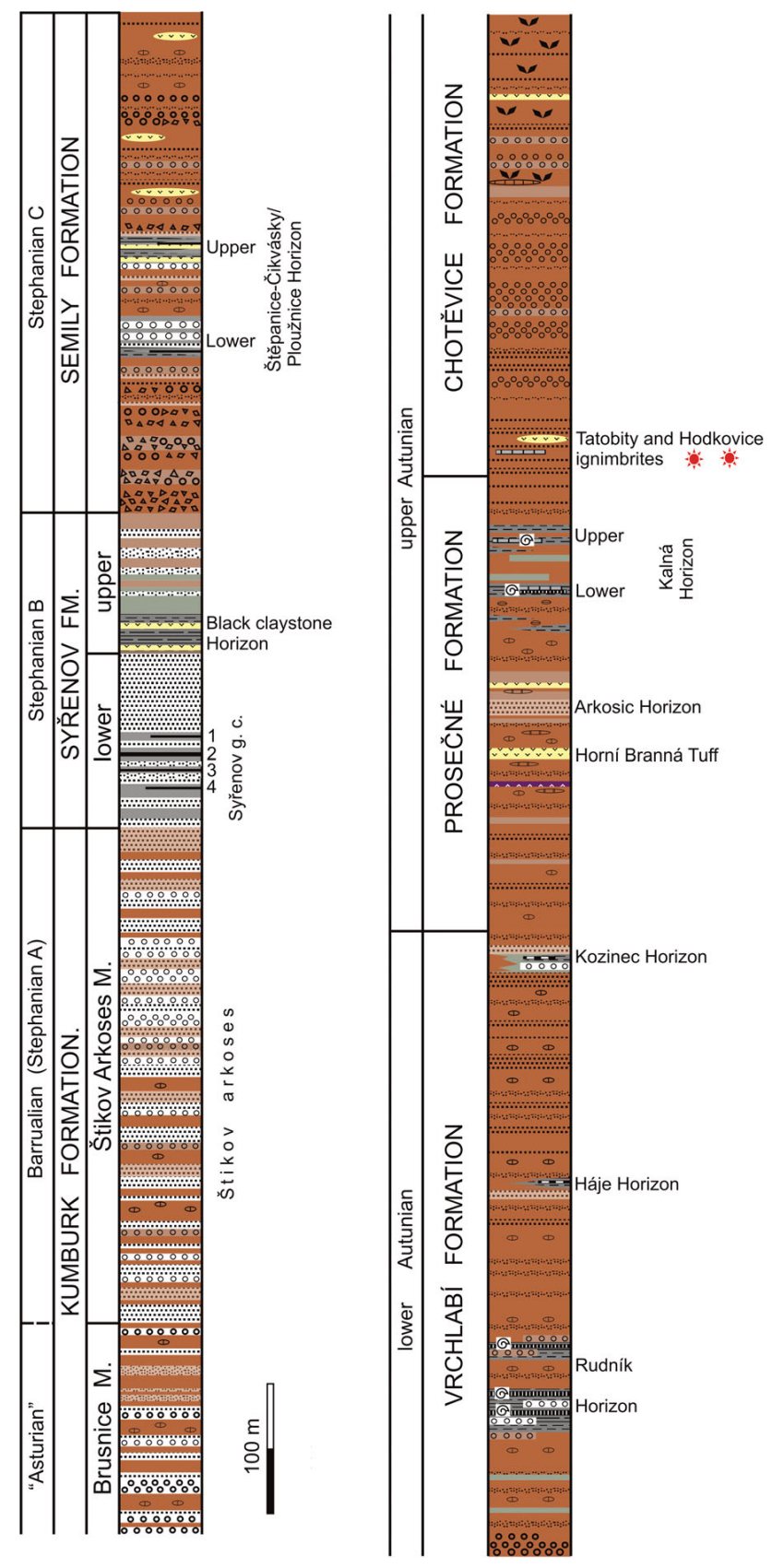

Figure 8. Idealised sections of the Krkonoše-Piedmont Basin and its stratigraphical subdivision and lithology of individual units. Based on data in Pešek et al. (2001). Location of dated samples is indicated. For explanation of lithology see Fig. 4.

stratigraphic equivalent in the southern part of the basin is the Ploužnice Horizon, that also comprises two several tens of meters thick discrete lacustrine horizons. Dominating are pale grey, variegated or red mudstones, claystones, and ripple bedded sandstones with intercalated red cherts and redeposited or in situ volcaniclastics (Tásler et al. 1981). The biostratigraphic record is rather controversial. The occurrence of blattoids Sysciophlebia rubida and Syscioblatta 
lawrenceana (Fig. 6) suggests a Late Kasimovian to Early Gzhelian age calibrated to the Global Marine Scale by co-occurences of insect zone species with conodonts and fusulinids in North America, roughly correlated to the European Stephanian B (Lucas et al. 2011, Schneider et al. 2013), whereas fish faunas represented by sphenacanthid and xenacanthid chondrosteans, acanthodians, and mainly actinopterygians Sphaerolepis kounoviensis, Spinarichthys dispersus (Fritsch, 1895) and Elonichthys sp. indicate rather a Stephanian C age of the horizons (Zajic 2007, 2014). The same age is suggested also by the flora (Fig. 5), which contains Odontopteris schlotheimii Brongniart, Callipteridium pteridium Gutbier and Autunian conferta (Sternberg) Kerp. This younger age is also in agreement with lithological correlation of these horizons with the Zdětín and Klobuky lacustrine horizons in the Líně Formation of the basins in central and western Bohemia (Pešek 1994, Pešek et al. 2001). This correlation is further supported by apparent similarity of floras of both areas. Several small volcanic bodies intercalated in the Semily Formation include andesitic effusives or less common rhyolites, mostly below the lacustrine Ploužnice Horizon. They mark the onset of intermediate to basic volcanic activity in Late Pennsylvanian times.

\section{Vrchlabí Formation}

The formation is a 300-500 m thick complex of mostly fluvial red beds and intercalated lacustrine strata of various lithologies (Fig. 8). Fluvial deposits are dominated by floodplain mudstones, which alternate with sheet-like finegrained sandstones. Channel facies are subordinate except in the southern part of the basin, where the dominating lithology is medium to coarse-grained sandstone. Lacustrine sediments are concentrated into three horizons. The thickest and laterally most widespread is the stratigraphically oldest Rudník Horizon, the thickness of which varies between 30 and $150 \mathrm{~m}$. It consists of grey to variegated mudstones, laminated claystones, limestones and bituminous claystones. Intercalated are volcaniclastic beds. The Rudník Horizon contains diverse and stratigraphically important fish fauna and flora (Figs 5, 6). Flora is rich in callipterids and conifers suggesting the Autunian age of the horizon (Opluštil et al. 2013a). This is in agreement with Asselian age indicated by fish species Acanthodes gracilis (Beyrich, 1848) and shark Bohemiacanthus carinatus (Fritsch, 1890), actinopterygians Paramblypterus rohani (Heckel, 1861), Neslovicella elongata Štamberg, 2010, as well as conchostracans Pseudoestheria breitenbachensis Martens, 1983 and Pseudestheria tenella (Bronn, 1850) (Schneider \& Zajíc 1994, Schneider 1996, Pešek et al. 2001). Remains of the branchiosaurid amphibian Melanerpeton sp. and of the crocodile-like amphibian Archegosaurus dyscriton (Steen, 1938) are rare. Stratigraphically younger, the 10 to $30 \mathrm{~m}$ thick Háje Horizon is traceable over a distance of about $8 \mathrm{~km}$ in the NW part of the basin. It consists of grey to green-grey mudstones with intercalated carbonaceous claystone to thin high-ash Háje Coal. Flora includes walchian conifers, calamites and ferns. The presence of Arndhardtia scheibei (Gothan) Haub. \& Kerp suggests late lower Autunian to upper Autunian age (Šimůnek in Pešek et al. 2001). In the top of the Vrchlabí Formation there is the 15-20 m thick Kozinec Horizon of grey sandstones, siltstones and copper-bearing mudstones locally with carbonaceous admixture. This horizon is of local extent, traceable over $2 \mathrm{~km}$ along the northern margin of the basin (Pešek et al. 2001). It provides a low diversity plant assemblage, which contains Odontopteris subcrenulata Rost, Neurodontopteris auriculata (Brongniart) Potonié and rare Autunia conferta (Sternberg) Kerp.

Deposition of the Vrchlabí Formation was accompanied by intensive intermediate to mafic volcanic activity, which spreads from the KPB further west into the MHB. The oldest effusive volcanic rocks are several to few tens of meters thick, mostly basaltic to andesitic lava flows overlying the Rudník and Háje horizons along the northern basin margin between Semily and Vrchlabí (Ulrych et al. 2004, 2006). The youngest basaltic to andesitic volcanites occur at the top of the Vrchlabí and base of the Prosečné formations, mainly in W and NW parts of the basin (Stárková et al. 2011). Here the andesitic lava flows are associated with deposits of pyroclastic flows and bedded airfall tuffs including accretionary lappili, and different types of autoclastic breccias (Schovánková 1985, Prouza \& Tásler in Pešek et al. 2001, Stárková et al. 2011). They are the result of Hawaiian-type eruptions with lava effusions followed by pyroclastics generated from Strombolian eruptions (Stárková et al. 2011). Related to the peak of volcanic activity is a sequence of 6 to 7 lava flows between Vrchlabí and Semily, from where they can be followed about $40 \mathrm{~km}$ NW along the Lusatian Overthrust in the eastern margin of the MHB (Fediuk 2001). In the northern part of this basin lava flows reach a cumulative thickness up to $500 \mathrm{~m}$ and dominate the basin fill (Pešek et al. 2001).

\section{Prosečné Formation}

This 300-400 m thick formation is dominated by red mudstones, which alternate with very subordinate fine-grained sandstones (Fig. 8). Intercalated are acid and basic volcanic rocks, mostly pyroclastics. At the top of lower part of the formation there are brick-red compositionally intermediate biotite-rich tuffs and volcanoclastic deposits, accompanied with up to few meters thick lava flows of basaltic andesites mostly of laterally limited extent (Rapprich in Prouza et al. 2010). The upper part of the formation contains several lacustrine intervals. The most important of them are the 
Figure 9. Lithostratigraphic units of the Krkonoše-Piedmont Basin and their stratigraphic ranges according to Pešek et al. (2001) and Pešek (2004) compared with subdivision suggested in this paper.

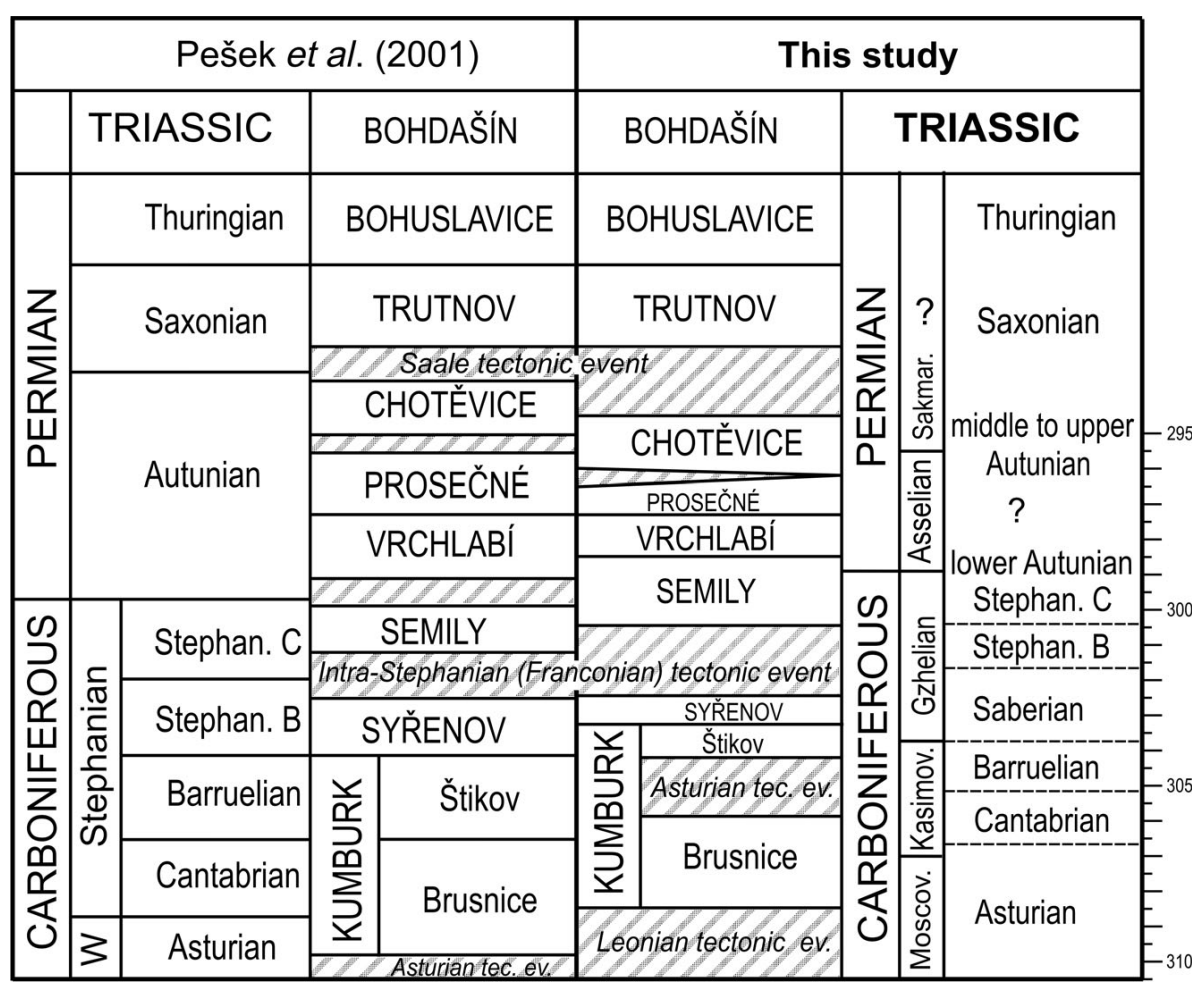

lower and upper Kalná Horizons (Fig. 8) composed of grey to variegated mudstones, claystones, marlstones and limestones, some of them being bituminous. Bituminous sediments of the lower Kalná Horizon contain a rich aquatic vertebrate fauna (Fig. 6) including shark Xenacanthus decheni Goldfuss, actinopterygians and branchiosaurid amphibians by Apateon sp. The limestone of the upper Kalná Horizon contain xenacanthid sharks, actinopterygians $\mathrm{Pa}$ ramblypterus zeidleri (Fritsch) and Aeduellidae indet., small branchiosaurid amphibians together with the large temnospondyl amphibian Cheliderpeton vranyi Frič. The plant assemblage is characterized by presence of Neurodontopteris auriculata (Brongniart) Potonié, Neurocallipteris neuropteroides (Goeppert) Cleal et al., Odontopteris subcrenulata Rost, O. lingulata (Goeppert) Schimper, and common walchian conifers. Callipterids are rare, represented only by Autunia conferta. The age of the formation is interpreted as upper Autunian (Pešek et al. 2001).

\section{Chotěvice Formation}

This formation consists of a $<400 \mathrm{~m}$ thick succession of fluvial red beds with alternation of polymict conglomerates, sandstones mudstones and thin beds of grey lacustrine limestones of local extent containing fish scales (Prouza et al. in Čech 2013; Fig. 8). The proportion of lithologies varies throughout the section. Brown-red mudstones in $\sim 100$ m thick upper part of the formation contain crystals, lenses or veins of anhydrite or its calcite pseudomorphs
(Pešek et al. 2001). The fossil record is poor and stratigraphically unimportant. However, the presence of Autunia conferta still suggests an Autunian age for the deposits.

Volcanic rocks are represented mostly by non-welded ignimbrite or weakly welded low-temperature ignimbrites of rhyolite to alkali rhyolite composition. These tens of metres thick bodies crop out near Tatobity along the western tectonic margin of the Krkonoše-Piedmont Basin. A similar volcano-sedimentary succession is exposed $15 \mathrm{~km}$ NW along the railway-cut north of Hodkovice nad Mohelkou (Fig. 3). Here the andesite pillow lava body is associated with dark-grey lacustrine claystone probably representing the Horní Kalná lacustrine horizon (Středa 1972) or similar horizon within the Prosečné Fm. Several tens of meters above there are few meters thick mixed volcanoclastic rocks (lahars) with pebbles of rhyolites, passing upwards into a $>100 \mathrm{~m}$ thick ignimbrite complex rich in pumice in its basal part.

\section{Methods}

Six lithostratigraphically constrained tuff, tonstein, and ignimbrite samples from the Intra-Sudetic and KrkonošePiedmont basins and adjacent eastern margin of the Mnichovo Hradiště Basin were investigated. Heavy mineral separates containing populations of moderate to highly elongated, prismatic zircon crystals were separated by conventional density and magnetic methods. The bulk zircon 


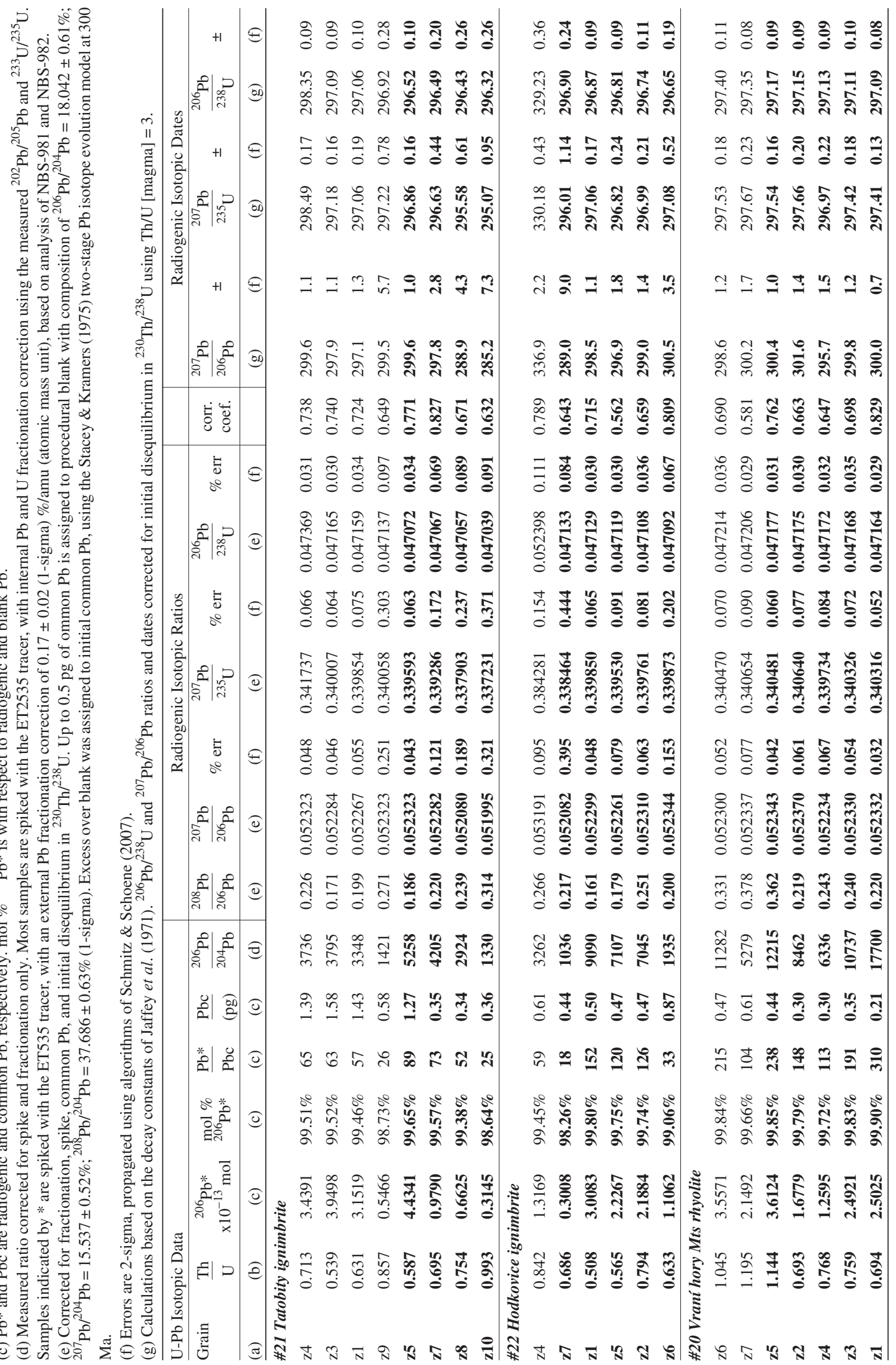


Stanislav Opluštil et al. • Late Paleozoic Sudetic basins radioisotopically dated

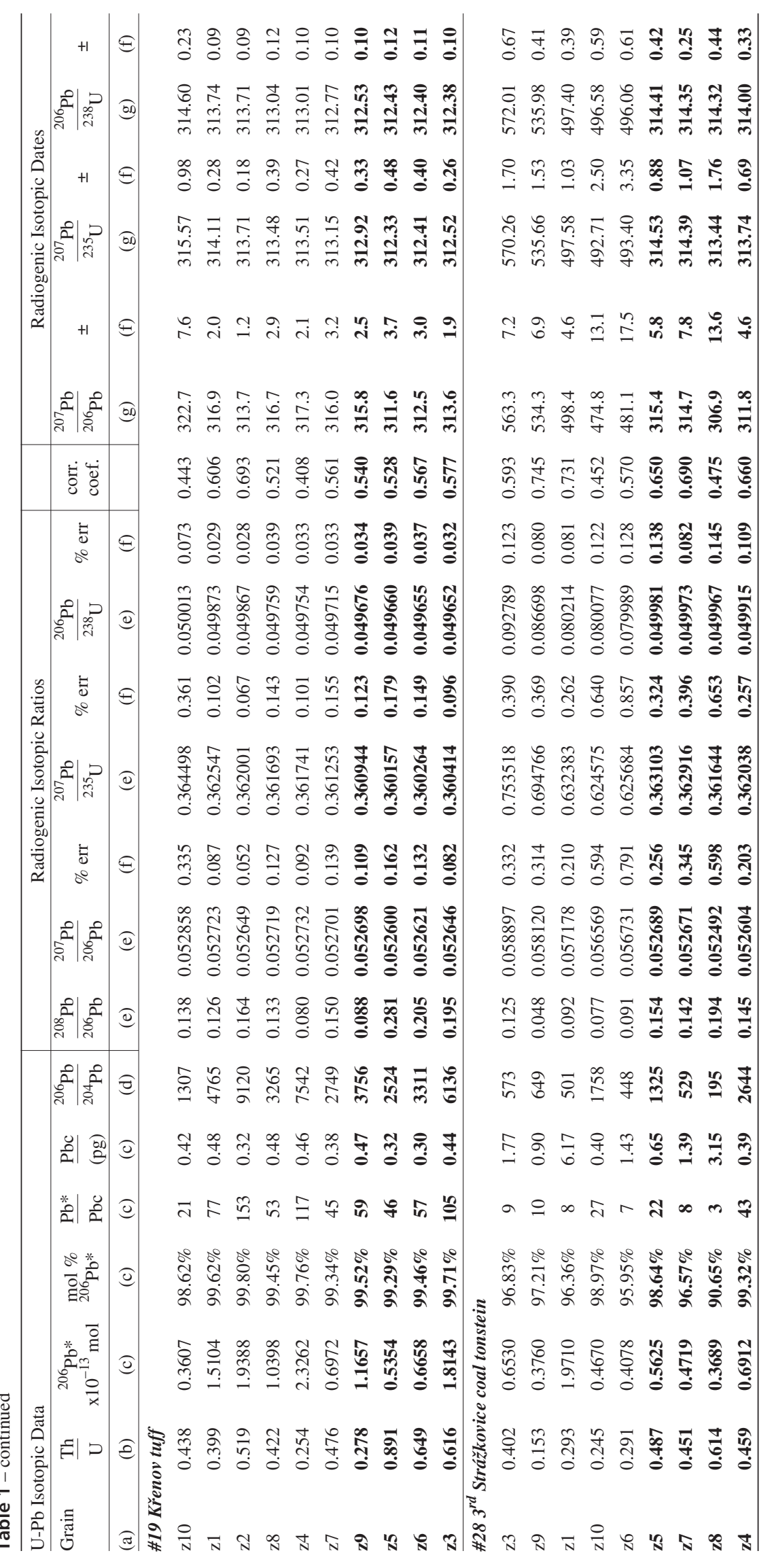




\begin{tabular}{|c|c|c|c|c|}
\hline \multicolumn{5}{|l|}{ CA-TIMS U-Pb age summary } \\
\hline Sample & Formation & ${ }^{206} \mathrm{~Pb} /{ }^{238} \mathrm{U}$ age $\mathrm{Ma} *$ & MSWD $\dagger$ & $\mathrm{N}$ \\
\hline \multicolumn{5}{|l|}{ Krkonoše-Piedmont Basin } \\
\hline \#21 Tatobity ignimbrite & Chotěvice & $296.49 \pm 0.08(0.12)[0.33]$ & 0.77 & 4 of 8 \\
\hline \#22 Hodkovice ignimbrite & Chotěvice & $296.81 \pm 0.05(0.10)[0.33]$ & 1.80 & 5 of 6 \\
\hline \multicolumn{5}{|l|}{ Intra-Sudetic Basin } \\
\hline \#20 Vraní hory Mts rhyolite & Broumov & $297.13 \pm 0.04(0.10)[0.33]$ & 0.54 & 5 of 7 \\
\hline \#19 Křenov ignimbrite/tuff & Žacléř & $312.44 \pm 0.05(0.11)[0.35]$ & 1.59 & 4 of 10 \\
\hline \#28 $3^{\text {rd }}$ Strážkovice coal ton. & Žacléř & $314.27 \pm 0.17(0.19)[0.38]$ & 1.17 & 4 of 9 \\
\hline
\end{tabular}

Table 2. U-Pb isotopic data. Notes: *All weighted mean ages at the $95 \%$ confidence interval, as calculated from the internal $2 \sigma$ errors expanded by the square root of the MSWD and the Student's T multiplier of n-1 degrees of freedom. Uncertainties are quoted as analytical (analytical+tracer) [analytical+tracer+decay constant]. $†$ mean squared weighted deviations. Numbers of samples as sent to the laboratory. separates for each sample were annealed in a muffle furnace at $900{ }^{\circ} \mathrm{C}$ for 60 hours in quartz beakers prepare the crystals for subsequent chemical abrasion (Mattinson 2005). For samples with larger grain sizes, $\mathrm{U}-\mathrm{Pb}$ isotopic analyses via chemical abrasion isotope dilution thermal ionization mass spectrometry (CA-ID-TIMS) were undertaken on mounted, polished and cathodoluminescence (CL) imaged crystals. For samples yielding grains too small for mounting, high aspect ratio crystals were targeted. In either case, individual crystals were chemically abraded using a single aggressive abrasion step in concentrated $\mathrm{HF}$ at $190{ }^{\circ} \mathrm{C}$ for 12 hours, and the residual crystals processed for isotope dilution thermal ionization mass spectrometry (ID-TIMS). Most samples were spiked with the ET2535 mixed U-Pb spike, whereby both $\mathrm{Pb}$ and $\mathrm{U}$ instrumental mass fractionation can be corrected using the internal ${ }^{202} \mathrm{~Pb} /{ }^{205} \mathrm{~Pb}$ and ${ }^{233} \mathrm{U} /{ }^{235} \mathrm{U}$ isotope ratios of the tracer. A handful of samples were analyzed with the ET535 mixed $\mathrm{U}-\mathrm{Pb}$ spike, and $\mathrm{Pb}$ fractionation corrected using an externally derived mass bias derived from the average $\mathrm{Pb}$ fractionation of the ET2535-spiked samples. The details of ID-TIMS analysis are described by Davydov et al. (2010) and Schmitz \& Davydov (2012). U-Pb dates and uncertainties for each analysis were calculated using the algorithms of Schmitz \& Schoene (2007), the U decay constants of Jaffey et al. (1971), and the ET2535 and ET535 spike compositions of Condon et al. (2015). Other details of analytical parameters can be found in the notes to the Table 1 . The quoted uncertainties in the Table 1 are based upon non-systematic analytical errors, including counting statistics, instrumental fractionation, tracer subtraction, and blank subtraction. These error estimates should be considered when comparing our ${ }^{206} \mathrm{~Pb} /{ }^{238} \mathrm{U}$ dates with those from other laboratories that used tracer solutions calibrated against the EARTHTIME gravimetric standards. When comparing our data with those derived from other decay schemes (e.g., ${ }^{40} \mathrm{Ar} /{ }^{39} \mathrm{Ar},{ }^{187} \mathrm{Re}-{ }^{187} \mathrm{Os}$ ), the uncertainties in tracer calibration $(0.03 \%$; McClean et al. 2015) and U decay constants $(0.108 \%$; Jaffey et al. 1971$)$ should be added to the internal error in quadrature. Sample ages are thus reported as $\pm \mathrm{X}(\mathrm{Y})[\mathrm{Z}] \mathrm{Ma}$, where $\mathrm{X}$ is the internal error, $\mathrm{Y}$ is the internal plus tracer calibration error, and $\mathrm{Z}$ is the internal plus tracer plus decay constant uncertainty (Table 2).
Ages obtained from zircons are interpreted as to represent the latest magmatic stage prior to the eruption and are thus excellent proxies to depositional ages of dated volcanic rocks.

Our new radio-isotopic data from the three basins were used to re-assess the ages of their lithostratigraphic units. Physical correlation of these units with those in the basins of central and western Bohemia via tens of boreholes (e.g. Havlena \& Pešek 1980, Tásler et al. 1981, Pešek 1994 and Pešek et al. 2001), using correlation markers (tuff beds, lacustrine horizons) and lithostratigraphic pattern, allowed for combination of radio-isotopic data from both areas (Opluštil et al. 2016). Subsequently, it enabled to establish a time-calibrated model for the entire Pilsen-Trutnov Basin Complex.

\section{Results}

One air-fall tuff (tonstein), one ignimbrite sample and one rhyolite lava from the ISB and one sample of ignimbrite from the KPB and one from the adjacent part of the MHB provided ages in agreement with their relative stratigraphic position. Below is a brief description of petrographic characteristics, stratigraphic position and isotopic age of the investigated samples. Their numbers are as sent to the laboratory and all data are illustrated on the concordia diagrams on Fig. 10.

\section{Geochronology of volcanic rocks of the Intra-Sudetic Basin (ISB)}

A fine-grained green-grey lithic tuff (Fig. 11A) at the base of the Lampertice Member (sample 18) was taken from the wall of a small abandoned quarry on the left side of the main road from Prkenný Důl to Žaclér, $110 \mathrm{~m} \mathrm{SE}$ of the Žaclér castle $\left(50^{\circ} 38^{\prime} 56.43^{\prime \prime} \mathrm{N}, 15^{\circ} 54^{\prime} 17.52^{\prime \prime} \mathrm{E}\right)$ was sampled for radioisotopic dating. Unfortunately, the studied sample yielded no zircon.

The $3^{\text {rd }}$ Strážkovice coal tonstein (sample \#28) is a 10 to $15 \mathrm{~cm}$ thick parting in the middle part of the most widespread and thickest coal of the Strážkovice group of coals in the Prkenný Důl-Žd'árky Member (Fig. 4). It is a pale 

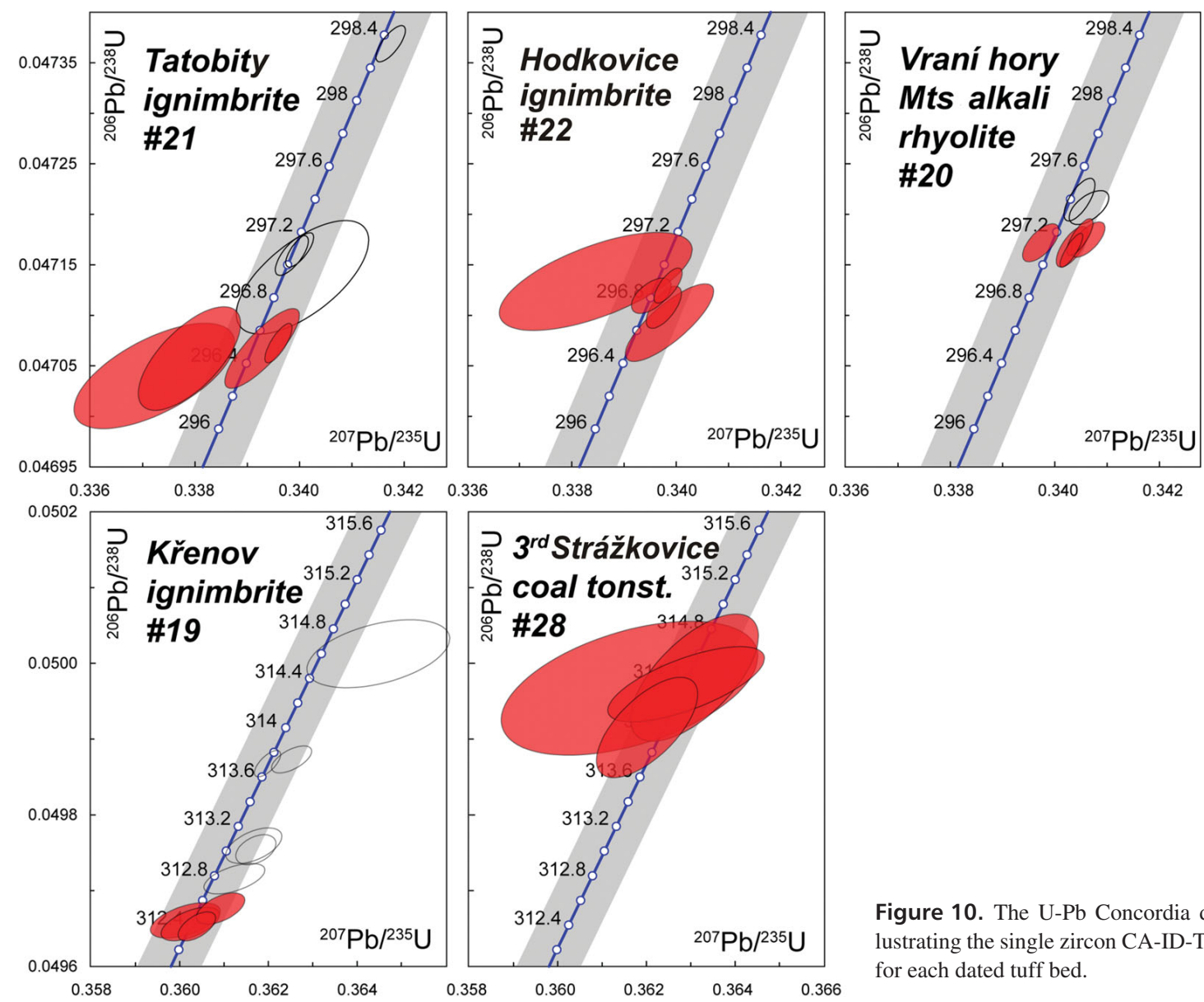

Figure 10. The U-Pb Concordia diagrams illustrating the single zircon CA-ID-TIMS results for each dated tuff bed.

green-grey fine-grained crystallovitric tuff of rhyolite composition passing upward into grey laminated volcanoclastic deposits and locally to mudstone at top. The tuff bears in situ preserved peat-forming flora (Opluštil et al. 2007). The stratigraphy of the tonstein is well constrained by the position of the coal in the upper part of the member, which, based on flora and palynomorphs, is of upper Duckmantian age (Pešek et al. 2001). This sample yielded a mixed zircon population dominated by rounded detrital grains but including a smaller proportion $(<10 \%)$ of small (fine sand to coarse silt-sized), equant to slightly elongate, prismatic zircon crystals. Nine prismatic zircon crystals were analyzed and yielded a range of Neoproterozoic to Carboniferous ages (Table 1). There is clear inheritance of reworked zircon in this sample, however all four of the Carboniferous grains are statistically equivalent and yield a weighted mean ${ }^{206} \mathrm{~Pb} /{ }^{238} \mathrm{U}$ date of $314.27 \pm$ $0.17(0.19)[0.38] \mathrm{Ma}$, which is interpreted as crystalization of magma shortly before eruption and thus principally identical with age of tuff deposition (Table 2).

The Křenov tuff/ignimbrite (sample \#19) is laterally the most widespread volcanic horizon of Carboniferous age in the Czech sector of the ISB. It is situated in the mid- dle to upper part of the Petrovice Member of Bolsovian age (Fig. 4). A sample of brick-red non-welded or slightly welded ignimbrite rich in lithic fragments was taken from natural outcrop on the left side of the valley between Prkenný Důl and Malý Křenov villages (50 $30^{\circ} 13,3^{\prime \prime} \mathrm{N}$, $\left.15^{\circ} 55^{\prime} 18.66^{\prime \prime} \mathrm{E}\right)$. The ignimbrite is underlain by 10 to $20 \mathrm{~m}$ thick coarse-grained conglomerate with cobbles derived from the underlying Krkonoše-Jizera Crystalline Unit. Below the conglomerate is a dark grey to grey-green fine-grained trachyandesite, which crops out in another abandoned quarry down the road. Microscopically the Křenov ignimbrite consists of magmatically coroded and fragmented quartz crystalloclasts (Fig. 11B), euhedral $\mathrm{K}$-feldspar (original sanidine is mostly strongly kaolinized) and baueritized biotite (phlogopite) with typical vermicular textures originating during quick cooling. Smaller K-feldspar and plagioclase crystallites are common in the groundmass, which consists of very finegrained ash with fluidally arranged titanomagnetite and illmenite pigment. Crystalloclastic structure prevails over vitroclastic one. The more welded part of the ignimbrite body contains glass shards and strongly flattened fiamme. The groundmass/crystaloclast ratio varies strongly. 
Large (medium to coarse sand), elongate, prismatic zircon crystals are abundant in this ignimbrite. Ten zircon crystals yielded dispersed apparent dates from 314.6 to 312.4 Ma; the four youngest grains comprise a population with a weighted mean ${ }^{206} \mathrm{~Pb} /{ }^{238} \mathrm{U}$ date of $312.44 \pm$ $0.05(0.11)[0.35] \mathrm{Ma}$, which is interpreted as the eruption of the ignimbrite (Tables 1,2). The older results are interpreted as mixtures of magmatic zircon and inherited cores from precursor magmatism.

The Vraní hory Mts alkali rhyolite to rhyodacite (sample \#20) is a 300-400 m thick volcanic complex (Fig. 4) interpreted as a succession of several lava flows (Kužvart \& Suk 1957). Recent observations in upper part of the quarry, however, reveal that massive rhyolitic to alkali rhyolitic lavas are penetrated by a large intrusion of trachyandesite to trachyte composition more than $100 \mathrm{~m}$ in diameter (Fig. 7). It suggests that the Vraní hory Mts volcanic complex may be interpreted as a cryptic lava dome with only limited indication of explosive volcanic activity (presence of acretionally lapilli). In thin section (Fig. 11C) the sample shows a porphyric texture with quartz, altered or kaolinized sanidine, and plagioclase phenocrysts. The plagioclase phenocrysts are often rimmed by thin layers of K-feldspars whereas the albite phenocrysts are rimmed by sanidine. The matrix is composed of a very fine-grained granular mosaic of quartz, feldspar and long prismatic ore minerals (titanomagnetite, ilmenite) suggesting very rapid cooling.

The dated sample of alkali rhyolite was sampled from the active quarry $1.64 \mathrm{~km} \mathrm{SE}$ of Královec on the SW slope of the Vraní hory Mts (5040’ $\left.0.44^{\prime \prime} \mathrm{N}, 15^{\circ} 59^{\prime} 25.79^{\prime \prime} \mathrm{E}\right)$. Large elongate prismatic zircons are abundant in this sample. Seven single zircon grain analyzed by CA-ID-TIMS yielded apparent dates ranging from 297.4 to 297.1 Ma (Table 1). Five of those analyses are concordant and equivalent with a weighted mean ${ }^{206} \mathrm{~Pb} /{ }^{238} \mathrm{U}$ date of 297.13 $\pm 0.04(0.10)$ [0.33] Ma, which is interpreted as the eruption and depositional age of the alkali rhyolite body (Table 2). The slightly older two analyses are interpreted as antecedent crystals or crystal zones from prior magmatism.

\section{Geochronology of volcanic rocks of the Krkonoše-Piedmont (KPB) and Mnichovo Hradiště (MHB) basins}

The Tatobity ignimbrite (sample \#21) is a $\sim 50 \mathrm{~m}$ thick rhyolite ignimbrite body embedded in the lower part of the Chotěvice Formation (Fig. 8). It crops out in the SW flank of the monocline separating the KPB and MHB. The ignimbrite body is dipping SW concordant to its hosting sedimentary strata. The sample of pinkish, reddish or light grey, massive and weakly welded to non-welded vitro- to crystaloclastic ignimbrite was collected in a small abando- ned quarry $500 \mathrm{~m}$ NE of village of Tatobity $\left(50^{\circ} 34^{\prime} 28.01^{\prime \prime} \mathrm{N}\right.$, $\left.15^{\circ} 16^{\prime} 44.20^{\prime \prime} \mathrm{E}\right)$. The ignimbrite in the quarry wall has typical columnar jointing. Strongly weathered reddish pumice-rich layers occur in the upper part of the section. Scarcely present are also angular clasts of fine grained andesite. Microscopically the crystal-rich Tatobity ignimbrite consists of rounded, hypidiomorphic bipyramidal or strongly fragmented quartz shards, mostly $1-3 \mathrm{~mm}$ in diameter, idiomorphic kaolinized sanidine, usually albitized and/or sericitized plagioclase, and xenomorphic and often broken and fragmented baueritized biotites in a very fine-grained ash matrix (Fig. 11D). It contains often folded and strongly flattened pumices (fiamme) rich in ore mineral pigment.

Eight elongate prismatic zircon crystals containing abundant melt inclusions were selected for analysis, and yielded apparent dates ranging from 298.4 to $296.3 \mathrm{Ma}$ arranged in three groups (Table 1, Fig. 10). The oldest single grain and a cluster of three grains with ages of 297.0 Ma are interpreted as inherited crystals. The youngest cluster of four grains yields a weighted mean ${ }^{206} \mathrm{~Pb} /{ }^{238} \mathrm{U}$ date of $296.49 \pm 0.08(0.12)[0.33] \mathrm{Ma}$, which is interpreted as the eruption and depositional age of the ignimbrite (Table 2).

The Hodkovice ignimbrite (sample \#22) was sampled from the railway cut NW of Hodkovice nad Mohelkou at the NE edge of the MHB (5040 $\left.26.93^{\prime \prime} \mathrm{N}, 15^{\circ} 05^{\prime} 51.05^{\prime \prime} \mathrm{E}\right)$. Here a narrow belt of Permian sediments and intercalated volcanic rocks crop out along the Lusatian Overthrust (Coubal et al. 2014), before plunging to the SW beneath the Cretaceous strata, which conceal nearly the entire MHB. The Hodkovice ignimbrite represents a continuation of similar bodies from the Tatobity area in the western margin of the KPB, and suggests its position in lower part of the Chotěvice Formation (Pešek et al. 2001). The dated sample is a slighly welded pinkish ignimbrite rich in fiamme of acid rhyolite composition with $76 \mathrm{wt} . \% \mathrm{SiO}_{2}$. It is composed of crystaloclasts of $<4 \mathrm{~mm}$ large automorphic to xenomorphic grains of quartz, K-feldspar, plagioclase, and baueritized biotite. The matrix contains great amounts of ore minerals (magnetite, secondary limonite and ilmenite) and subordinate smaller fragments of quartz, plagioclase, and fine-grained flakes of dark brown strongly pleochroic biotite. Dark brown flattened pumices (fiammes) and dark red or grey to black angular lithic fragments of underlying andesite are locally common.

Large (medium sand) elongate prismatic zircon crystals are abundant in this ignimbrite, and five single grains yielded a weighted mean ${ }^{206} \mathrm{~Pb} /{ }^{238} \mathrm{U}$ date of $296.81 \pm$ 0.05(0.10)[0.33] Ma, which is interpreted as the eruption and depositional age of the ignimbrite (Tables 1, 2; Fig. 10). A single substantially older xenocryst of zircon was also analyzed, but discarded from the age calculation. 

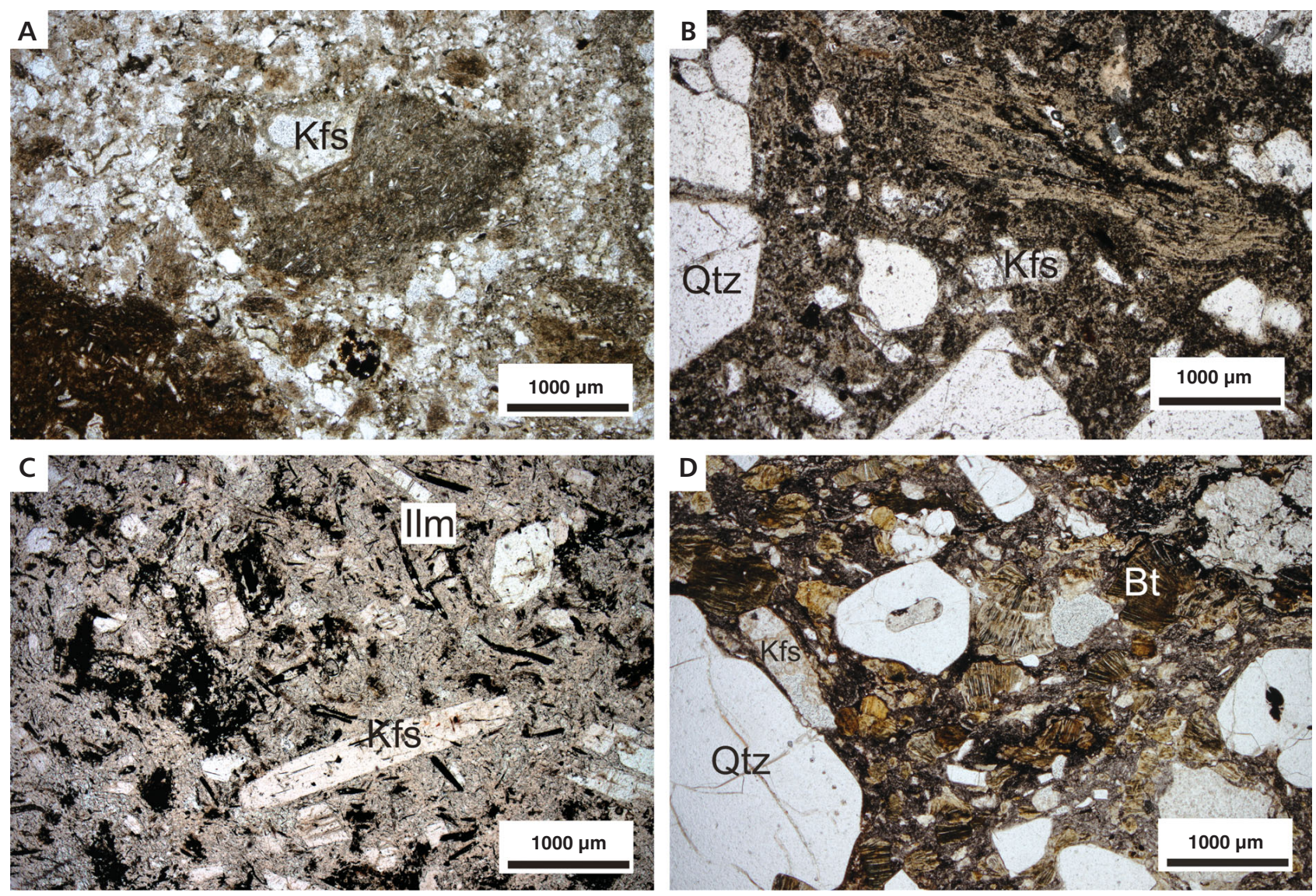

Figure 11. Examples of microstructures of some volcanic rocks described in the text. $\bullet A-$ fragments of porphyritic trachyandesite in the fine-grained fluidal matrix of dacitic composition. Lithic tuff at base of the Lampertice Member, abandoned quarry near Žacléř, ISB. • B - non-welded Křenov ignimbrite. Common biotite with vermicular textures resulting from fast cooling, loc. Malý Křenov, Petrovice Member. • C- alkali rhyolite with long prismatic idiomorphic phenocrysts of sanidine and long prismatic crystals of ilmenite, proving fast cooling. Notice a randomly oriented growth of both phenocrysts and matrix minerals and a fine-grained felsic matrix in comparison with ignimbrites. Active quarry NE of Bernartice (Vraní hory Mts), Broumov Fm., ISB. • D - weakly welded ignimbrite from abandoned quarry SE of Tatobity, Chotěvice Fm., KPB.

\section{Discussion on the Intra-Sudetic and Krkonoše-Piedmon basin stratigraphies}

The new radioisotopic data from the ISB, KPB and adjacent eastern margin of the MHB allow for re-interpretation of the chronostratigraphic position of some lithostratigraphic units. In addition, lithostratigraphic correlation between the Sudetic and the central and western Bohemian basins, based on a dense borehole network (Havlena \& Pešek 1980; Pešek 1994, 2004; Pešek et al. 2001), allows for combination of radioisotopic data from both areas. Together these radio-isotopic ages of syn-depositional volcanic rocks significantly improve our understanding to tectonic and sedimentary history of all these continental basins of the Pilsen-Trutnov Basin Complex, and volcanic activity during late Paleozoic time. This, in turn, has a profound impact on the calibration and correlation of the terrestrial biozones identified in the basins under study to global stages and marine biozones (Schneider et al. 2014).
Traditional biostratigraphic approach is based on rich compression flora (Pešek et al. 2001 for overview), which enables to establish existing floral biozones originally defined by Wagner (1984). Remnants of fauna are much less common except for some lacustrine horizons in Late Pennsylvanian and Cisuralian part of the basin succession. Among the various faunal groups the use of amphibians for non-marine biostratigraphy seems to be currently the most sophisticated being based on evolutionary lineages (Werneburg \& Schneider 2006, Schneider \& Werneburg 2012). The teeth of xenacanth sharks have been also applied for correlation between some European basins (Schneider \& Zajíc 1994, Schneider 1996). On the contrary, actinopterygian fishes, besides the biozonation of the Late Carboniferous and Early Permian basins of the Bohemian Massif introduced by Zajíc (2000), have not been used for biostratigraphy of European Carboniferous and Permian basins. The major reason is a possibly limited exchange of fish faunas among landlocked basins, which is responsible 
for differences in stratigraphic ranges of taxa and endemism. This implies that fish "biozones" suggested by Zajíc (2000) are rather of local biostratigraphic value restricted only to the Pilsen-Trutnov Basin Complex and potentially some other basins connected via river drainage (e.g. Boskovice Basin). As suggested by many authors (e.g. Pešek 1994; Pešek et al. 1998, 2001), most of the continental basins of the Bohemian Massif were already paleogeographically interconnected in Late Pennsylvanian time. It allowed for migration of fish species among these basins. The abundance of actinopterygians in these basins together with other vertebrates allows exploiting them for correlation of some fossiliferous horizons.

\section{The Intra-Sudetic Basin}

There are no volcanic bodies in the Blażkow Formation and, in turn, no radioisotopic data are available. Consequently, the late Viséan to early Namurian age of this oldest unit in the Czech part of the basin remains constrained only biostratigraphically (Šetlík in Tásler et al. 1979).

In the overlying Žaclér Formation two new radioisotopic ages are available; one in the Prkenný DůlŽd'árky and the second in the Petrovice members. The oldest part of the formation, the Lampertice Member, remains as interpreted from macroflora, i.e. ranging between late Namurian and early late Duckmantian (Šimůnek in Pešek et al. 2001). Numerical ages of the unit can be inferred from calibrated regional stages (Davydov et al. 2010) to within an interval $319.5-316$ Myr.

In the following Prkenný Důl-Žd'árky Member, the tonstein of the $3^{\text {rd }}$ Strážkovice Coal provided a radioisotopic age $314.44 \pm 0.17 \mathrm{Ma}$ (Table 2), which corresponds to the early Bolsovian in the calibrated chart of Davydov et al. (2010) based on data from the Donets Basin. We, however, prefer the late Duckmantian based on a $313.78 \pm 0.08 \mathrm{Ma}$ CA-ID-TIMS age for the Z1 tonstein in the Ruhr Basin, Germany (Pointon et al. 2012), which is located $\sim 10 \mathrm{~m}$ below the regionally widespread Aegiranum Marine Band, the base of which defines the Duckmantian/Bolsovian boundary (Owens et al. 1985). The radioisotopic age of the $3^{\text {rd }}$ Strážkovice coal tonstein is thus in agreement with late Duckmantian macroflora of the Prkenný Důl-Žd'árky Member (Šimůnek in Pešek et al. 2001). Based on macrofloral criteria, however, the Duckmantian/Bolsovian boundary is virtually unrecognisable (Wagner 1984; Cleal 2005, 2007), which makes its identification in continental setting without marine bands impossible. Instead the base of the Paripteris linguaefolia Zone is often used to approximate the Duckmantian/Bolsovian boundary (Wagner 1984). The base of this biozone lies in the late Duckmantian and is marked by the first appearance of a number of species that characterize younger Westphalian macrofloras, such as Mariopteris nervosa, Macroneuropteris scheuchzeri, whereas some older taxa including species of the genus Lonchopteris decrease in abundance or disappear. All of these changes take place also in the Prkenný Důl-Žd'árky Member, which confirms the late Duckmantian position of the whole member (Pešek et al. 2001). Flora of the Prkenný Důl-Žd'árky Member is closely comparable with the flora from the Lower Radnice Member in central and western Bohemia, except the rare occurrence of the genus Lonchopteris in the latter unit (Němejc 1953).

The Petrovice Member at top of the Žaclér Formation is now calibrated by the new radioisotopic age of the Křenov ignimbrite/tuff complex in the upper part of the member (Fig. 4). Its Bolsovian age $(312.39 \pm 0.10 \mathrm{Ma})$ is in agreement with both macrofloras (Šetlík 1977) and the published numerical age of this sub-stage (Gradstein et al. 2012, Pointon et al. 2012, Opluštil et al. 2016) and contrasts with its previously determined ${ }^{40} \mathrm{Ar} /{ }^{39} \mathrm{Ar}$ sanidine plateau age of $309.3 \pm 4.6 \mathrm{Ma}$ (Lippolt et al. 1986). Flora of the lower part of the Petrovice Member is similar to that of the Prkenný Důl-Žd'árky Member, however, in its upper part Annularia sphenophylloides, A. stellata and Linopteris obliqua appear (Fig. 5). In central and western Bohemia these species appear in the Upper Radnice Member, which is assigned to the middle-late Bolsovian Linopteris rarinervis Sub-zone in upper part of the Paripteris linguaefolia Zone (Opluštil et al. 2016). The similarity of the Petrovice and Upper Radnice member floras is in agreement with nearly identical radioisotopic ages of volcanic rocks intercalated in both units; i.e. the Křenov ignimbrite/tuff in the Petrovice Member and Green Tuff and its equivalent Black Tuffite in the Upper Radnice Member. Their ages vary within a narrow interval between 312.36 and 312.39 \pm 0.10 Myr (Table 2).

The Odolov Formation is separated from the underlying Žacléř Formation by a biostratigraphically proved hiatus, which spans the latest Bolsovian and lower "Asturian" and ranges across the entire Linopteris bunburi Zone (Šetlík 1977). No radioisotopic ages have been obtained from this unit. Therefore, the chronostratigraphic position of the formation and its members are inferred from their correlation with corresponding strata in basins of central and western Bohemia (e.g. Havlena \& Pešek 1980, Pešek et al. 1994), where six tuff beds were dated (Opluštil et al. 2016). The Svatoňovice Member in the lower part of the Odolov Formation provided upper Asturian and Cantabrian flora nearly identical with that of the Nýřany Member in central and western Bohemian basins (Šetlík 1977) that is typical of Crenulopteris acadica and Odontopteris cantabrica zones (Opluštil et al. 2016). Based on radioisotopic data from the basins in central and western Bohemia, the Svatoňovice Member can be numerically constrained approximately within an interval of 308.3-305.8 Myr (Fig. 12). 
Stanislav Opluštil et al. • Late Paleozoic Sudetic basins radioisotopically dated

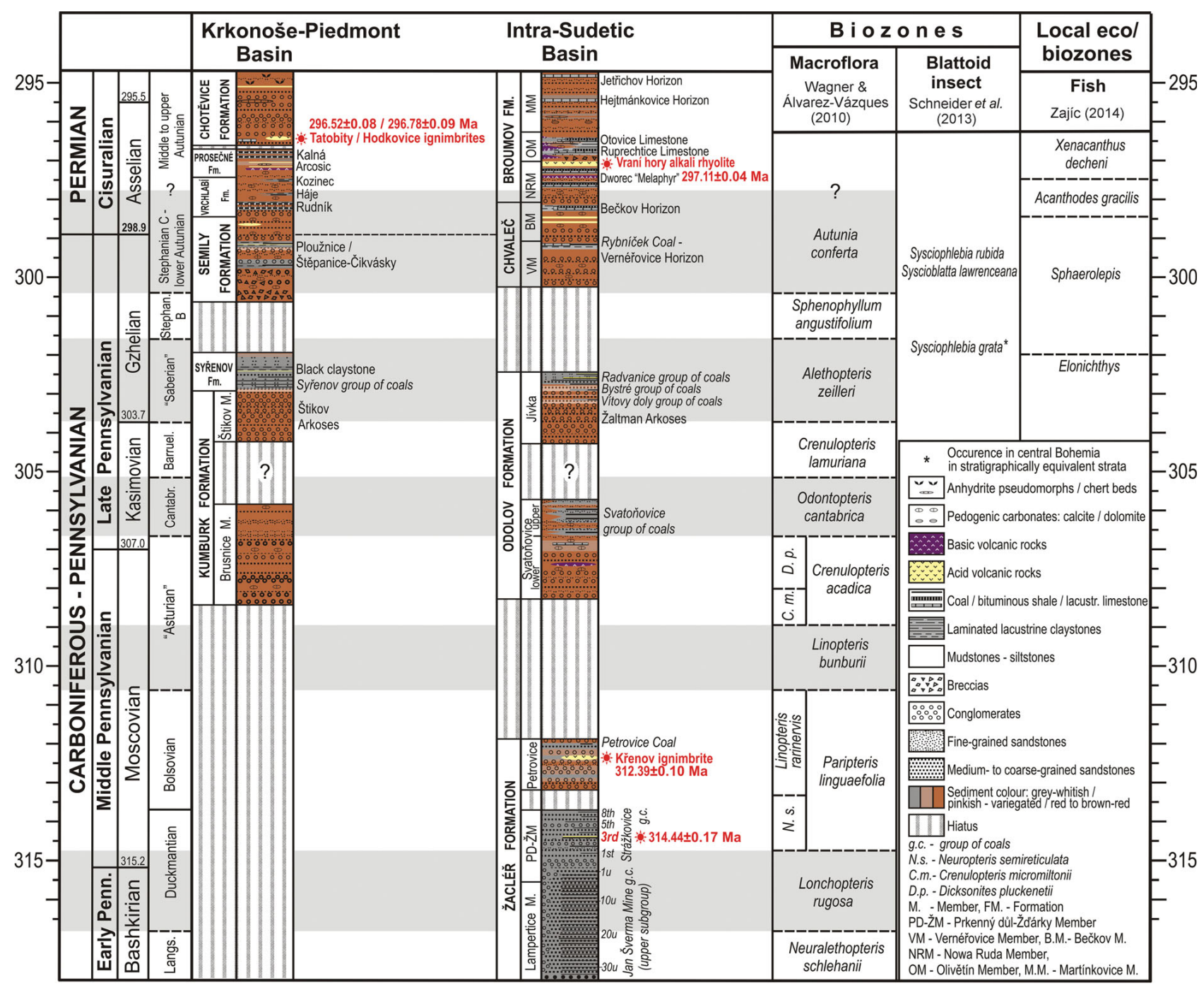

Figure 12. Chronostratigraphical position of the lithostratigraphical units and biozones in the Intra-Sudetic and Krkonoše-Piedmont basins. Correlation of both basins is suggested based on their calibration by new radio-isotopic data and correlation markers. Ages for the top and base of lithostratigraphical units are extrapolated. Ranges of regional substages (Wagner 1984, and Wagner \& Álvarez-Vázques 2010) are adapted to newly calibrated floral biozones.

The Jivka Member in the upper part of the Odolov Formation is traditionally constrained within the Barruelian (Stephanian A) and Stephanian B interval based on its position within the basin succession and flora (Šetlík 1977, Tásler et al. 1979, Pešek et al. 2001). The major part of the member consists of the Žaltman Arkoses, coarse-grained feldspatic sandstones and conglomerates with thin intercalations of red mudstones and a very poor fossil record restricted mostly to long-ranging taxa. Lithological character and presence of silicified gymnospermous woods led Tásler et al. (1979) and Pešek et al. (2001) to the conclusion that this part of the Jivka Member is a stratigraphic equivalent to the Barruelian Týnec Formation in central and western Bohemian basins. The upper part of the Jívka Member comprises grey coal-bearing intervals the major one being the Radvanice group of coals. Its flora is of late
Stephanian B age, now re-interpreted by Wagner \& Álvarez-Vázquez (2010) as Saberian (Fig. 5). The Radvanice group of coals is correlated with the Syřenov and Mělník group of coals in the Krkonoše-Piedmont and Mšeno-Roudnice basins respectively (Pešek et al. 2001, Pešek 2004). New radioisotopic data from equivalent strata in central and western Bohemian basins proved the existence of a hiatus between the Kladno and Týnec formations (Fig. 13), suggested by Wagner (1977), who noted the absence of Crenulopteris (formerly Lobatopteris) lamuriana Zone. This gap is related to the Asturian tectonic event and in the Intra-Sudetic Basin is located between the Svatoňovice and Jívka members.

Deposition of the following Chvaleč Formation took place after a floristically recognised hiatus (Šetlík 1977, Tásler et al. 1979, Pešek et al. 2001). The unit lacks 
radioisotopic data and its Stephanian $\mathrm{C}-$ Autunian age is constrained only from infrequent macroflora and fauna (Tásler et al. 1979). Presence of callipterid species Autunia naumannii and Dichophyllum flabellifera in the Rybníček Coal of the Vernéřovice Member led Havlena \& Pešek (1980) to assign the entire formation to the Autunian. However, since both callipterid species and actinopterygian fish Sphaerolepis kounoviensis Frič, 1876 already occur in the latest Carboniferous (e.g. Kerp 1988), Šimůnek in Pešek et al. (2001) located the Carboniferous/Permian boundary above the Rybníček Coal in the upper part of the Vernéřovice Member.

The stratigraphically highest pre-Saalean unit is the Broumov Formation, which is undoubtedly of Autunian age (Tásler et al. 1979, Pešek et al. 2001) as indicated by its biostratigraphic record, now confirmed by the new radioisotopic age of the Vraní hory Mts volcanic complex in upper part of the Nowa Ruda Member. The sample from the lower part of the complex provided an age of $297.11 \pm$ 0.04 Ma. Remaining units, the Olivětín and Martínkovice members in middle and upper parts of the formation, are assigned to the upper Autunian by Šimůnek in Pešek et al. (2001). Schneider \& Werneburg (2012) correlate the Broumov Formation with the Asselian and lower part of Sakmarian stages of the Global Stratigraphic Chart. This interpretation is principally confirmed by our new radioisotopic age, which in combination with thickness of the formation suggests extrapolation of the top of the Broumov Formation approximately to the Asselian/Sakmarian boundary or slightly above it, i.e. at $\sim 295 \mathrm{Ma}$ (Figs 12, 13).

\section{The Krkonoše-Piedmont Basin}

The basal unit is the Kumburk Formation, which in the southern part of the basin is sub-divided into Brusnice and Štikov members. The poor floristic record of these red beds allow for only vague stratigraphic assessment. Although no radioisotopic ages have been obtained from the Kumburk Formation, progress in understanding of its stratigraphic position can be achieved via correlation with the stratigraphically equivalent strata in the Intra-Sudetic and central and western Bohemian basins (e.g. Tásler et al. 1981, Pešek et al. 1998). Thus the Brusnice Member is considered a stratigraphic equivalent of the Svatoňovice Member in the Intra-Sudetic Basin, which is floristically correlated with the Nýřany Member (Figs 12, 13), radioisotopically constrained within an interval between $~ 305.9$ and 308.3 Myr (Opluštil et al. 2016). The Štikov Member in the upper part of the Kumburk Formation is lithologically very similar to the Žaltman Arkoses in the Jivka Member of the Intra-Sudetic Basin and to the calibrated Týnec Formation in the basins of central and western Bohemia (e.g. Tásler et al. 1981, table 1; Pešek 1994; Pešek et al. 1998, table 7). If this correlation, based on overal lithological similarity and character of their fossil record is correct, as suggested by the absence of Crenulopteris lamuriana Zone, there is the same hiatus as revealed by radioisotopic calibration between the Kladno and Týnec formations in the basins of central and western Bohemia (Opluštil et al. 2016). This gap related to the Asturian tectonic event spans an interval of nearly $2 \mathrm{Ma}$ and divides the Kumburk formation into two parts, possibly corresponding to its subdivision into Brusnice and Stikov members (Figs 12, 13).

The Syřenov Formation lacks radioisotopic data, however, its stratigraphic position is well constrained by lithostratigraphic and biostratigraphic correlations with corresponding units in the Intra-Sudetic and central and western Bohemian basins (Figs 12, 13). Reliability of the borehole correlation is stressed by the presence of the most important and laterally widespread correlation marker in the Upper Paleozoic continental basins of the Bohemian Massif, which is the Mšec Horizon in the basins of central and western Bohemian and its equivalent Black Claystone Horizon in the Krkonoše-Piedmont Basin (e.g. Havlena \& Pešek 1980, Pešek 1994). Below this lacustrine horizon are locally developed and economically important coal groups (Mělník, Syřenov and Radvanice - Fig. 13). Flora is uniform across the basins (Šetlík 1977) and represents the Alethopteris zeilleri Zone formerly assigned to the Stephanian B, now considered to represent the Saberian substage (Opluštil et al. 2016). It corresponds to the lower Gzhelian and based on radioisotopic calibration of equivalent strata in the basins of central and western Bohemia (Opluštil et al. 2016) the Syřenov Formation can be constrained within an interval 302.9-302.1 Myr depending on depth of erosion during the hiatus following the deposition of the formation (Fig. 13).

The overlying Semily Formation was deposited after a biostratigraphically constrained hiatus and its floristic record led Šetlík (1977) and Šimůnek in Pešek et al. (2001) to assign this formation into Stephanian $C$ and lower Autunian. No radioisotopic data are available and therefore understanding the stratigraphic position of the formation is, besides the biostratigraphic data, inferred from its correlation via boreholes to the basins in central and western Bohemia. Pešek (1994) and Opluštil et al. (2013a) correlate the lacustrine lower and upper Ploužnice horizons of the Semily Formation with the Zdětín and Klobuky horizons of the Líně Formation, respectively, the latter horizon being radioisotopically calibrated (Opluštil et al. 2016). This correlation is in agreement with floral data of all these horizons, typical of the Autunia conferta Zone, and with the occurence of actinopterygian fish Sphaerolepis kounoviensis Frič, 1876. We accept this correlation in our study and, with respect to the thickness of the Semily Formation constrain this unit approximately within an interval 


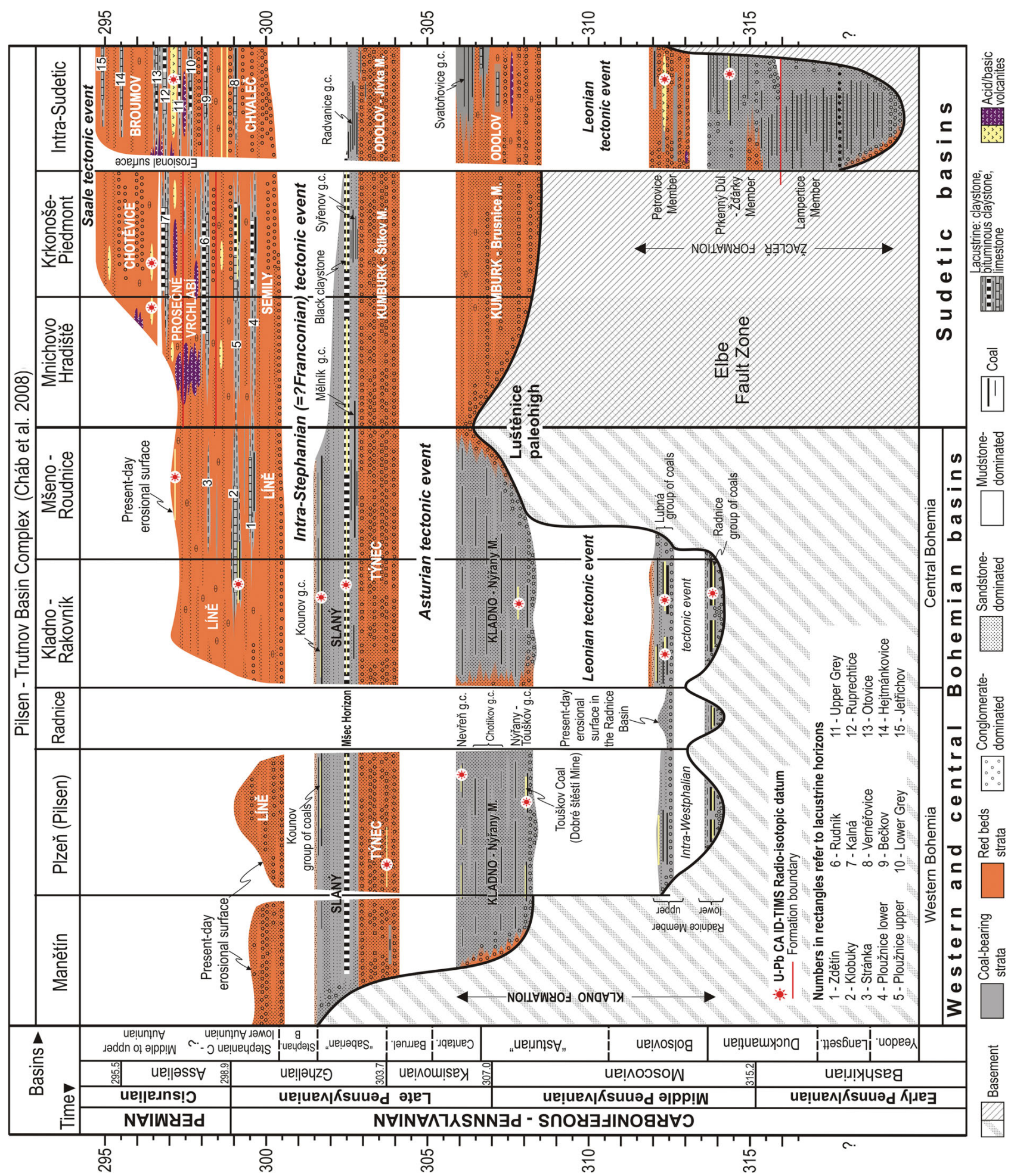

Figure 13. Tectono-sedimentary model of the Pilsen-Trutnov Basin Complex calibrated by new high-precision radio-isotopic data from the Sudetic basins and basins in central and western Bohemia (Opluštil et al. 2016). Stratigraphic position of the dated samples indicated.

300.6 and 298.5 Myr (Fig. 11). It corresponds to the late Gzhelian and lower Asselian of the Global Stratigraphic Chart.
The occurrence of Sphaerolepis kounoviensis, the index taxon, was also confirmed from the coal of Rybníček (Verneřovice Member, Chvaleč Formation) in the Intra-Sudetic 
Basin (Štamberg \& Zajíc 2008). Most common finds of Sphaerolepis kounoviensis come, however, from the Kounov Member (Saberian) of the Kladno-Rakovník Basin and from other localities in lower part of the overlying Líně Formation in the central and western Bohemian basins (Štamberg \& Zajíc 2008). It is obvious that this species migrated among basins of the Bohemian Massif and it was their stable occupant. Occurrence of Sphaerolepis kounoviensis is restricted to the deposits of the Late Pennsylvanian only; it does not occur in the Permian sediments of the Bohemian Massif based on our new radioisotopic data (Opluštil et al. 2016). It allows us to correlate the Ploužnice Horizon in the Krkonoše-Piedmont Basin with the Rybníček coal/Vernéřovice Horizon in the IntraSudetic Basin and also with the Zdětín and Klobuky horizons in the Kladno-Rakovník and Mšeno-Roudnice basins in Central Bohemia (Fig. 13).

The Vrchlabí Formation is generally considered to be of Autunian age based on flora and fauna (Zajíc 2000, 2014; Pešek et al. 2001; Schneider \& Werneburg 2012; Opluštil et al. 2013a; Štamberg 2014). Unfortunately no radioisotopic ages are available and therefore we can only very roughly constrain position of the formation to the interval 298.5-297.3 Myr (Fig. 11). This interval is inferred from the interpolation between calibrated intervals in the Semily and Chotěvice formations.

Four horizons with actinopterygians and other vertebrate fauna were distinguished in the Krkonoše-Piedmont Basin (Štamberg 2014). The stratigraphically lowermost assemblage lies within the Rudník Horizon (Vrchlabí Formation). Actinopterygians, including Paramblypterus rohani (Heckel), Neslovicella elongata Štamberg, Igornichthys sp. and Letovichthys sp., are accompanied by abundant Acanthodes gracilis (Beyrich) and Bohemiacanthus carinatus (Fritsch), rarely by isolated remains of the dipnoan Ctenodus tardus Fritsch. Amphibians are represented by Melanerpeton sp. and Archegosaurus dyscriton (Steen), but rare. An adequate assemblage is not known in the Intra-Sudetic Basin. Therefore the correlation of the Rudník Horizon in the Krkonoše-Piedmont Basin with the lacustrine Bečkov Horizon in the Intra-Sudetic Basin is based only on lithostratigraphic correlation. Rare disarticulated fish remains in the Bečkov Member are not determinable at present and cannot be used for biostratigraphic correlation.

The Prosečné Formation is biostratigraphically constrained within the lower part of upper Autunian (Pešek et al. 2001). Although no numerical ages of intercalated volcanic rocks are available, a late Asselian age of the volcanic body from the base of the overlying Chotěvice Formation constrains the Prosečné Formation to the late Asselian as well (Fig. 12).

Actinopterygians and other aquatic vertebrates in embedded lacustrine horizons allow for their correlation to lacustrine fauna-bearing sediments in the ISB. The stratigraphically lowermost the lower Kalná Horizon, which contain actinopterygians including Paramblypterus kablikae (Geinitz), P. feistmanteli (Fritsch) and very rare $P$. rohani (Heckel) (Štamberg 2014), shark Xenacanthus decheni, Goldfuss and the branchiosaurid amphibian Apateon sp. seems to be missing in the Intra-Sudetic Basin.

The upper Kalná Horizon contains two beds of grey claystone and reddish limestone with actinopterygians (Štamberg 2014). They crop out on several sites between Dolní Kalná and Arnultovice, and contain actinopterygians of the family Aeduellidae and paramblypterids including Paramblypterus zeidleri (Fritsch). Another abundant Paramblypterus is designated at present as Paramblypterus "type B" (Štamberg, 2014), and it is very close to Paramblypterus vratislaviensis (Agassiz), which is common in the Ruprechtice Horizon (Olivětín Member) of the Intra-Sudetic Basin. Chondrichthyans Xenacanthus decheni (Goldfuss), branchiosaurid amphibians and a large temnospondyl amphibian Cheliderpeton vranyi Frič occur together with actinopterygians in the upper Kalná Horizon. This assemblage overlaps to significant part (Fig. 6) with that in the Ruprechtice Horizon in the ISB and demonstrates correpondence of these horizons. Species common for both horizons include the actinopterygians Paramblypterus zeidleri and Paramblypterus "type B", which is very close to $P$. vratislaviensis, Xenacanthus decheni, branchiosaurid amphibians and Cheliderpeton vranyi.

The Chotěvice Formation is the youngest of the pre-Saale tectonic event units of the Krkonoše-Piedmont basin. Pešek et al. (2001) suggest a hiatus between this and the underlying Prosečné formations. New radioisotopic late Asselian ages (Tables 1,2) from the Tatobity and Hodkovice ignimbrites in the lower part of the formation suggest that this hiatus is only of a very short duration (Fig. 12). This conclusion differs from a Kungurian age suggested by Schneider \& Werneburg (2012) or a purely Sakmarian age interpreted by Zajíc (2014). Our extrapolation suggests a late Asselian to early Sakmarian age of the formation.

\section{Tectono-sedimentary history of the Pilsen-Trutnov Basin Complex}

The Intra-Sudetic, Krkonoše-Piedmont and the Mnichovo Hradiště basins represent the eastern part of a much larger complex of sedimentary basin, which extends from the NE edge of the Bohemian Massif further west into central and western Bohemia (Fig. 1), and since beginning of the Late Pennsylvanian connected in a single Pilsen-Trutnov Basin Complex. Although thickness and lithology of individual lithostratigraphic units may vary across this $10,000 \mathrm{~km}^{2}$ large area, the basic stacking lithostratigraphic pattern is 
traceable across the entire basin complex (Pešek et al. 2001). This pattern includes not only alternation of lithologically similar and stratigraphically corresponding major units, but also lacustrine horizons or intervals of increased volcanic activity (Pešek 1994, Pešek et al. 2001). In agreement between various parts of the basin complex is also a temporal distribution of "climatic" indicators marked by basin-wide alternation of fluvial red beds and grey coal-bearing strata, climate-sensitive sediments, the alternation of ecologically different dryland/wetland floras, and the type of fossilization (DiMichele et al. 2010, Opluštil et al. 2013a, DiMichele 2014). This lithostratigraphic pattern is in agreement with biostratigraphic data, which allow for correlation to regional substages. Our new radioisotopic ages together with similar data from the central and western Bohemian basins (Opluštil et al. 2016) confirm basin-scale isochroneity of this pattern and allow for estimation of numerical ages of lithostratigraphic units. Results of this stratigraphic re-assessment are summarized in the spatio-temporal tectono-sedimentary model of the central and western Bohemian and Sudetic basins, which together form the Pilsen-Trutnov Basin Complex (Fig. 13). The model shows sub-isochronous alternation of sedimentary intervals separated by hiatuses across the entire area. This alternation is interpreted as a result of tectonically driven base-level changes and, in turn, in alternation of periods of deposition and erosion. These base-level changes are result of the changes in plate configurations, which in turn result in accumulation of stress at plate boundaries producing short-lived tectonic deformation events affecting the whole European Variscan belt (Schulmann et al. 2014). As a result, similar breaks interrupted deposition in other coeval basins of central Europe (e.g. Cleal et al. 2010, Schneider et al. 2015), however, detailed comparison with them is beyond the scope of this study. During periods of base-level drops predominating erosion of older strata produced basin-scale erosional surfaces with a topography up to tens of meters (Skopec et al. 2001). Longer periods of erosion also disrupted the continuity of floral succession. Tectonic processes changed the geometry of the depocenter and in some cases resulted in gentle tilting of older strata (Skopec \& Pešek 2005). In the basin hinterland tectonic activity rejuvenated landscape topography and increased supply to the basin of coarse detritus (Tásler et al. 1979, Spudil 1999, Pešek et al. 2001). In addition, differences in subsidence rate during base-level rise resulted in spatial variability of thickness of strata of the same age.

Significant variability exists also in the duration of deposition in particular sub-basins of the Pilsen-Trutnov Basin Complex. The longest period of deposition took place in the Intra-Sudetic Basin, where in the Czech part sedimentation started in the late Viséan and including several hiatuses lasted until the Triassic. It represents $80 \mathrm{Myr}$ years of depositional history. However, we deal in this analysis only with the pre-Saale tectono-sedimentary interval ranging from the Žaclér to the Broumov formations. Its duration is estimated from radioisotopic data as $\sim 24.7 \mathrm{Myr}$, of which 8.1 Myr comprise four hiatuses. In the Krkonoše-Piedmont Basin deposition lasted for $\sim 60 \mathrm{Myr}$, however, sedimentation until the Saale tectonic event spans the interval of about 13.5 Myr. It includes three hiatuses that lasted for $3 \mathrm{Ma}$ in all. In the basins of central and western Bohemia deposition spans 17.1 Myr including four hiatuses, the duration of which is estimated to take 7.5 Myr in all (Opluštil et al. 2016). Briefly described in subsequent text are five depositional intervals separated by four tectonic events recorded in the continental basins of the western and northern part of the Bohemian Massif.

\section{Late Namurian to late Duckmantian depositional interval ( 319.5-313.7 Myr)}

This oldest depositional interval we deal with is the best represented in the Intra-Sudetic Basin. It comprises the Lampertice and Prkenný Důl-Žd'árky members of the Žaclér Formation (Fig. 13). Thickness of this coal-bearing interval varies greatly due to basement paleotopography and different tectonic subsidence between 0 and 900 m (Tásler et al. 1979, Spudil 1999). It is dominated by bedload deposits of braided fluvial systems alternating with floodplain-dominated strata bearing coals and deposited probably in a meandering river system (Opluštil et al. 2013b). The uppermost part of the interval is in central and western Bohemia represented by the coal-bearing Lower Radnice Member, interpreted as a fill of river valleys (Opluštil $2005 \mathrm{a}, \mathrm{b}$ ). This correlation is supported by both macroflora and overlapping radioisotopic ages of volcaniclastics embedded in the Prkenný Důl-Žd'árky and Lower Radnice members (Šetlík 1977, Opluštil et al. 2016).

\section{Hiatus of the Intra-Westphalian tectonic event ( 313.7-313.2 Myr)}

This newly identified intra-Bolsovian hiatus interrupted deposition between the Prkenný Důl-Žd'árky and Petrovice members in the Intra-Sudetic Basin and between the Lower and Upper Radnice members in the basins of central and western Bohemia. Its duration is estimated at 0.5-1.1 Myr, being longer in latter area. Biostratigraphically it is located within the Paripteris linguaefolia Zone, which explains why it has not been biostratigraphically recognised earlier. Its possible existence in the KladnoRakovník Basin was first suggested by Opluštil (2003, 2005a). He identified a regional erosional surface between the Upper Radnice and Lower Lubná coals with relief up to $15 \mathrm{~m}$ and suggested the existence of a short hiatus below the resolution of biostratigraphic methods. Its existence is now proved by new radioisotopic data (Opluštil et al. 2016). This hiatus is 
in agreement with angular coal clasts in basal conglomerates and coarse sandstones derived from the Upper Radnice Coal during formation of the erosional surface (Pešek \& Sýkorová 2006). A similar hiatus was recognised also outside the Bohemian Massif. In NW Spain this event is assigned to the Palentian tectonic event (e.g. Wagner et al. 1977).

\section{Late Bolsovian depositional interval ( 313.2-311.9 Myr)}

This late Bolsovian interval includes the up to $350 \mathrm{~m}$ thick Petrovice Member in the Intra-Sudetic Basin and up to $100 \mathrm{~m}$ thick Upper Radnice Member in central and western Bohemia (Fig. 13). The Petrovice Member comprises bed load-dominated fluvial red beds with subordinate grey intervals, which in its upper part bear thin coals, whereas the upper Radnice Member is mostly a coarse-grained grey coal-bearing unit except at its top above the Lubná group of coals (Opluštil et al. 2015). Their correlation is supported by very similar macroflora (Šetlík 1977) and now confirmed by nearly identical radioisotopic ages of the Křenov Ignimbrite (Fig. 4, Tables 1, 2) in the Petrovice Member and the Black Tuffite and its lateral equivalent Green Tuff in the Upper Radnice Member. It is assumed that deposition of the thicker Petrovice Member lasted longer than that of the Upper Radnice Member.

\section{Hiatus of the Leonian tectonic event ( 311.9-308.3 Myr)}

This event is recorded as a hiatus separating the Žaclér and Odolov formations in the Intra-Sudetic Basin, and the Radnice and Nýřany members in the basins of central and western Bohemia (Fig. 13). It is the longest hiatus in the pre-Saale history of the basin complex and is well constrained by macroflora (Němejc 1958; Šimůnek in Pešek et al. 2001). It comprises the late Bolsovian and early "Asturian" and biostratigraphically ranges across the upper part of the Paripteris linguaefolia, entire Linopteris bunburii and lower part of Crenulopteris acadica zones (Fig. 12). Originally considered as the Asturian phase (Havlena 1964), it was later assigned to the Leonian phase by Opluštil \& Pešek (1998) following the similar but shorter tectonic event in the NW Spain, which spans the early "Asturian" stage (Wagner et al. 1977). Similar break separates also the Flöha and Zwickau formations in the Erzgebirge Basin, Saxony as well as the Łaziska and the Libiąż beds in the Upper Silesian Basin (Cleal et al. 2010).

\section{Late Asturian-Cantabrian depositional interval ( 308.3-305.7 Myr)}

After the Leonian tectonic event, deposition for the first time spread across the entire Pilsen-Trutnov Basin Com- plex. This depositional interval includes the Svatoňovice Member of the Odolov Formation in the Intra-Sudetic Basin, the Brusnice Member of the Kumburk Formation in the Krkonoše-Piedmont and Mnichovo Hradiště basins, and the Nýrany Member of the Kladno Formation in the basins of central and western Bohemia (Fig. 13). While the Nýřany Member is dominantly a grey coal-bearing unit with locally intercalated coal-barren red beds (Pešek 1994), its equivalents in the Mnichovo Hradiště, Krkonoše-Piedmont and the Intra-Sudetic basins are dominantly fluvial red beds. The only exception is the Upper Svatoňovice Member, which comprises two several tens of meters thick grey coal-bearing intervals of the Svatoňovice coal group of Cantabrian age. This lateral variability in term of dominating color of sediments and coal content is not well understood and may be related to the different intensity of drainage across the depocenter, and by redeposited lateritic weathering products from source areas (Skoček \& Holub 1968).

\section{Hiatus of the Asturian tectonic event ( 305.7-304.2 Myr)}

This hiatus includes the late Cantabrian and most of the Barruelian (Figs 12, 13), which comprises probably the top of the Odontopteris cantabrica and most, if not all of the Crenulopteris lamuriana zones. Its existence was first suggested by Wagner (1977), who noted the presence of a stratigraphically younger flora in the Týnec Formation. The existence of the hiatus, however, was not widely accepted (Pešek 1994, 2004; Pešek et al. 2001) until new radioisotopic ages from the basins in central and western Bohemia proved its existence (Opluštil et al. 2016). It spans a very similar stratigraphic range as the tectonic event of the same name in NW Spain (Stille 1920, Wagner et al. 1977).

\section{Late Barruelian-early Stephanian B depositional interval ( 304.2-302.0 Myr)}

This interval includes the Jivka Member in the Intra-Sudetic Basin, Štikov Member of the Kumburk Formation and the entire Syřenov Formation in the Krkonoše-Piedmont Basin, and the Týnec and Slaný formations in the basins of central and western Bohemia. Correlation of these units is based on a complex and laterally widespread lithological pattern, which is traceable across the entire Pilsen-Trutnov Basin Complex. The lower part of the depositional interval comprises bedload dominated fluvial red beds, which bear silicified woods, whereas the upper part consists of dominantly grey fluvial to lacustrine coal-bearing strata. The lower "red" part of the interval is in central and western Bohemia represented by the Týnec Formation, the thickness of which increases from about 
Stanislav Opluštil et al. • Late Paleozoic Sudetic basins radioisotopically dated

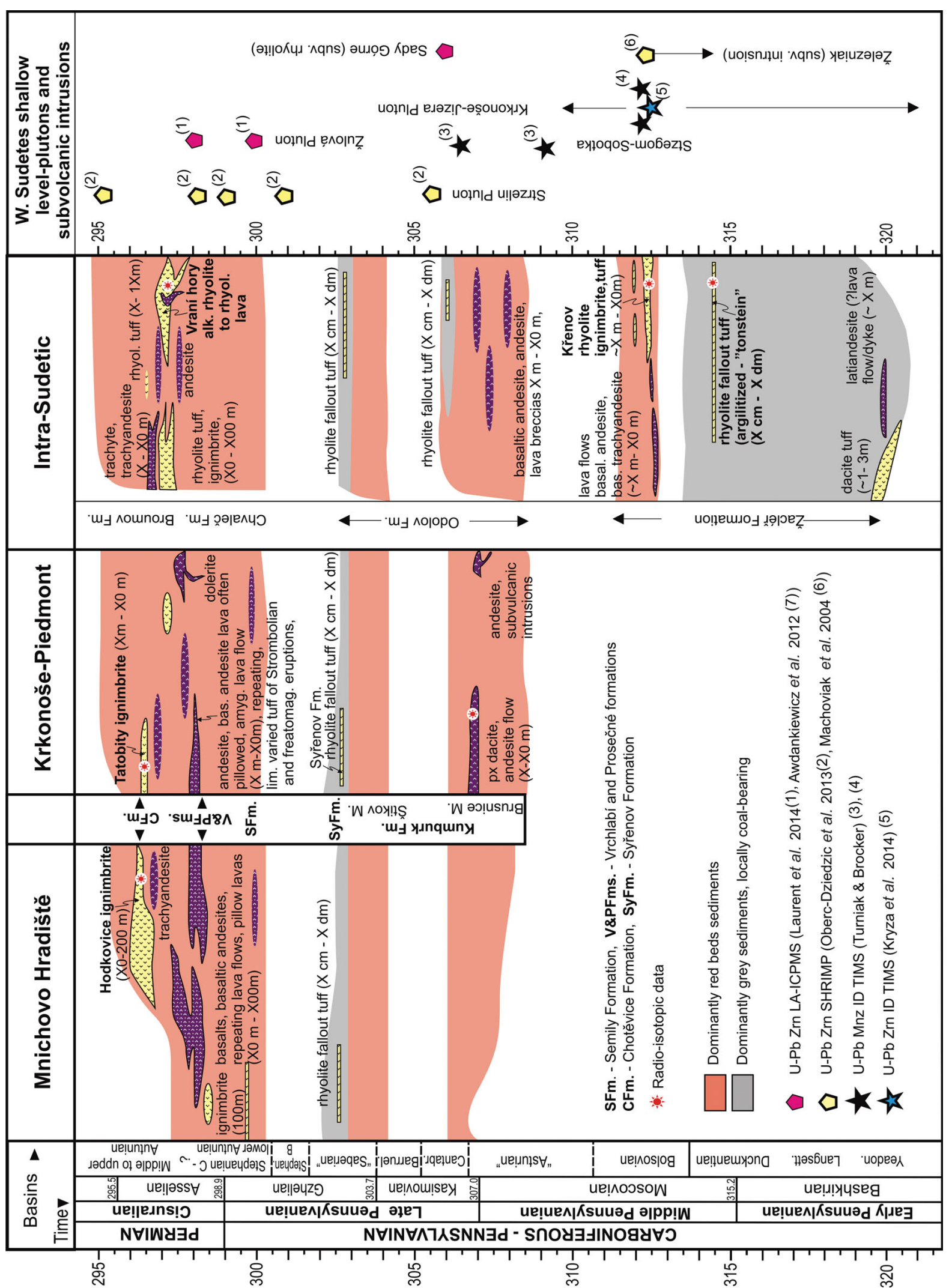

Figure 14. Correlation scheme of volcanic rocks within the Intra-Sudetic, Krkonoše-Piedmont and Mnichovo Hradiště basins based on the precise radiometric dating by ID TIMS method on zircons from volcanogenic horizons (airfall tufs, ignimbrite flows, rhyolite subvolcanic rock). Lacustrine horizons, which can be correlated across the Pilsen-Trutnov Basin Complex are used to correlate the sequences without radioisotopically dated samples. 
$30 \mathrm{~m}$ in the Manětín Basin to $170 \mathrm{~m}$ in the Kladno-Rakovník Basin (Fig. 13). The equivalent Štikov Member in the Krkonoše-Piedmont Basin is about $340 \mathrm{~m}$ thick and the Žaltman Arkoses in the Intra-Sudetic Basin reach up to 800 m (Fig. 12; Pešek 1994, Pešek et al. 2001). The reduction of thickness further west is related to decreasing subsidence rate and in the Manětín Basin is also due to later onset of the deposition on the basement. The upper "grey" part of the interval is of average thickness between 70 and $220 \mathrm{~m}$ in the basins of central and western Bohemia, whereas the same unit (Syřenov Formation) in the Krkonoše-Piedmont Basin is about 120 m thick (Tásler et al. 1981). In the Intra-Sudetic Basin the grey upper coal-bearing part of the Jívka Member reaches a thickness of $300 \mathrm{~m}$ (Tásler et al. 1979). However, the widest stratigraphic range of this grey part of the interval is recorded in the basins of central and western Bohemia, where the Kounov coal group is situated on top of the lacustrine-delta complex above the Mšec Horizon. In the KrkonošePiedmont Basin only the lacustrine delta complex above the Black Claystone Horizon (equivalent of the Mšec Horizon) is preserved whereas in the Intra-Sudetic Basin the "grey" interval is mostly reduced only to the part below the Black Claystone Horizon. This reduction is probably due to erosion during a subsequent hiatus (Figs 12, 13).

\section{Hiatus of the Intra-Stephanian (Franconian) tectonic event ( -302.5-300.0 Myr)}

This short hiatus ranges between $~ 301.6-300.6$ Myr in the basins of central and western Bohemia (Opluštil et al. 2016) and 300.0-302.5 Myr in the Intra-Sudetic Basin (Figs 12, 13). This is related to a deeper erosion of the underlying strata during the hiatus and possibly also to later onset of deposition of the Chvaleč Formation.

\section{Stephanian C-upper Autunian depositional interval ( $2300.6 / 300.0-\sim 295.0 \mathrm{Myr})$}

This interval is in full stratigraphic range present only in the Intra-Sudetic and Krkonoše-Piedmont basins, whereas the youngest strata in the basins of central and western Bohemia are of an extrapolated age of 297.1 Ma (Opluštil et al. 2016). The interval consists of fluvial to lacustrine red beds and intercalated grey lacustrine horizons usually several tens of meters thick. The interval comprises the Chvaleč and Broumov formations in the Intra-Sudetic Basin, the Semily, Vrchlabí, Prosečné and Chotěvice formations in the Krkonoše-Piedmont Basin, and the Líně Formation in the basins of central and western Bohemia. The stratigraphic range of the Líně Formation greatly varies due to different subsidence rates and intensity of postsedimentary erosion. The youngest strata in central Bohemia approximately correspond to the top of the Prosečné
Formation and the top of the Nowa Ruda Member of the Broumov Formation. Internal correlation of this thickest depositional interval is via lacustrine horizons, some of which (e.g. the Ploužnice and Rudník horizons and their equivalents) are believed to be spread over most of the basin complex. Some other lacustrine horizons are very local, e.g. the Háje and Kozinec. In Figs 12 and 13 we suggest a correlation scheme for the major horizons, supported by flora and fauna in combination with new radioisotopic data from intercalated volcanic rocks. In the KrkonošePiedmont Basin there is a short hiatus between the Prosečné and Chotěvice formations, the duration of which is only poorly biostratigraphically constrained (e.g. Tásler et al. 1979, Pešek et al. 2001, Schneider \& Werneburg 2012, Zajíc 2014). New radioisotopic ages from the Krkonoše-Piedmont and Mnichovo Hradiště basins, however, suggest only a very short duration of the hiatus (Fig. 12).

\section{Volcanic activity of the Intra-Sudetic and Krkonoše-Piedmont basins and their correlation with magmatic events}

The Late Carboniferous to Early Permian volcanic activity of the ISB, KPB and the MHB is concentrated into several phases (Fig. 14).

Volcanic rocks of the first phase (late Namurian) are of local extent and volume and are represented by fine-grained ignimbritic breccias, trachyandesite to dacite tuffs and a small andesitic body found at base of the Lampertice Member.

Products of the second phase of volcanism (late Bashkirian-middle Moscovian) comprise tonsteins in some coals of the Prkenný Důl-Žd'árky Member (Tásler et al. 1979), however, the peak was reached during deposition of the Petrovice Member accompanied by formation of several lava bodies and the Krrenov ignimbrite/tuff complex (Figs 4, 14). A late Duckmantian age of $314.27 \pm$ $0.17 \mathrm{Ma} \mathrm{U}-\mathrm{Pb}$ age of the tonstein in the $3^{\text {rd }}$ Strážkovice Coal is similar to $315-316 \mathrm{Ma}$ U-Pb zircon ages of highlevel granodiorite-granite intrusions of the Kaczawa Mts, connected with lava domes and lacollith composed of rhyodacitic ignimbrites and sherulitic rhyolites (Machoviak et al. 2004). It shows the close spatial relationships of shallow-level plutonic bodies with volcanic or subvolcanic facies. The Křenov ignimbrite/tuff complex $(312.39 \pm 0.10 \mathrm{Ma})$ overlaps in age with $312.5 \pm 0.3$ to $312.2 \pm 0.3 \mathrm{Ma}$ ID-TIMS ages (Kryza et al. 2014) of S-type granites of the Krkonoše-Jizera Pluton (Žák et al. 2013, Kusiak et al. 2014), Pluton. SHRIMP U-Pb zircon ages of $312.8 \pm 2.8 \mathrm{Ma}$ and 312.4 \pm 4 Ma for andesite dykes and lamprophyres cutting older acid volcanic and subvolcanic rocks, suggest that mantle-derived mafic melts are closely 
spatio-temporaly related to the crustally-derived acid melts. It further indicates that underplating of mantle-derived mafic melt caused melting of lower crust and production of more acid melts (Ulrych et al. 2004). These melts mixed at deep levels and fractionated and mingled during their ascent to the surface or during repeated infilling and replenishment of magma chambers.

The third phase of Carboniferous volcanism (late Moscovian-early Kasimovian) is expressed by subordinate bodies of poorly porphyritic pyroxene-bearing lavas with fine-grained matrix. Their composition varies mostly from basaltic trachyandesite to trachyte. They form up to several tens of meters thick lava flows with typical flat magmatic foliation within the Brusnice Member in the KPB. Similar bodies are known also from the Lower Svatoňovice Member in the ISB. Their ages overlap with the major explosive event in the Teplice-Altenberg volcanic complex (308.8 $\pm 4.9 \mathrm{Ma}$, Hoffmann et al. 2009) and with the $306.4 \pm$ $0.8 \mathrm{Ma}$ age of the Stzegom composite pluton emplaced along the NW-SE striking Sudetic Marginal Fault (Turniak \& Bröcker 2002, Kryza \& Awdankiewicz 2012).

Volcanic activity of late Kasimovian to early Gzhelian times is restricted to only thin fall out tuff beds (tonsteins) intercalated in coals of the Syřenov and Radvanice groups. Increase in volcanic activity starts in late Gzhelian times, which marks onset of the fourth and most voluminous phase of volcanic and magmatic activity in the Sudetic basins (Fig. 14). Early volcanic rocks are represented mostly by volcaniclastics, in the Vernéřovice Member and the Semily Formation, the latter containing also few andesitic lava flows. However, the peak of basaltic to andesitic volcanism with subordinate trachybasalts and trachyandesites (Fig. 14) is reached in early Asselian times and corresponds with deposition of the Vrchlabí and Prosečné formations in the KPB and MHB basins, and the stratigraphically equivalent Broumov Formation in the ISB. Stacked basaltic andesite and andesite lava flows tens of meters of cumulative thickness predominate mainly within and above the Rudník and Háje horizons in the KPB. Similar bodies of basalts and andesites of the Dworec melaphyres occur in the lower part of the Broumov Formation in the Javoři hory Mts along the eastern flank of the ISB. This volcanic event is calibrated by our new U-Pb CA-ID TIMS ages of overlying the Tatobity (296.49 \pm $0.08 \mathrm{Ma})$ and Hodkovice $(296.81 \pm 0.05 \mathrm{Ma})$ ignimbrites and little younger Vraní hory Mts rhyolite (297.13 \pm $0.04 \mathrm{Ma})$. Outside the Sudetic basins, the volcanics of overlapping ages or younger (up to $280 \mathrm{Ma}$ ) are common in the Variscan belt including Saxothuringicum, e.g. the youngest member of the Teplice-Altenberg volcanic complex, the Rochlitz ignimbrite and the North Sudetic Basin (Timmerman 2004, Hoffmann et al. 2013, Oberc-Dziedzic et al. 2013, Awdankiewicz et al. 2014, Laurent et al. 2014).

\section{Conclusions}

The new U-Pb CA-ID-TIMS high-precision ages of volcanic horizons in the ISB, KPB and the MHB allow for age-calibration of some lithostratigraphic units of these basins and re-assessment of the timing of their deposition and coeval volcanic activity. The existing dense borehole network in the Late Paleozoic continental basins of central and western Bohemia and in the Sudetic basins, and overall similarity of their stratigraphically equivalent strata, including wide-spread lacustrine horizons, allow for a detailed physical correlation between these two areas. This in turn, enables combination of our new radioisotopic data with similar high precision U-Pb CA-ID-TIMS ages from central and western Bohemia (Opuštil et al. 2016), and to establish an integrated stratigraphical model for the entire PilsenTrutnov Basin Complex. This time-calibrated model shows intervals of tectonically driven base level changes resulting in basin-wide alternation of periods of deposition and erosion. Macroflora described by previous authors from these basins was used to assign the lithostratigraphic units to particular floral biozones and their correlation to existing faunal zones. In addition, radioisotopic data allowed calibrating these floral biozones as well as some terrestrial/fresh-water faunal biozones and their correlation to global stages and thus contribute to integrated and radioisotopically calibrated marine/non-marine biostratigraphy.

Our integrated radioisotopically calibrated model of tectono-sedimentary history of the Pilsen-Trutnov Basin Complex and coeval volcanic activity shows (that):

- The existence of two new radioisotopically detected hiatuses in the Sudetic basins, the existence of which has not been so-far biostratigraphically identified. The older of them separates the Prkenný Důl-Žd'árky and Petrovice members (Žacléř Formation) in the ISB and spans the interval between $\sim 313.7$ and 313.2 Ma. The younger hiatus separates the Svatoňovice and Jivka members of the Odolov Formation in the Intra-Sudetic Basin and the Brusnice and Štikov members of the Kumburk Formation in the Krkonoše-Piedmont Basin. It spans the interval 305.7-304.2 Ma. Both hiatuses have been newly proved also in the basins in central and western Bohemia.

- Tectonically driven alternations of intervals of deposition and erosion are traceable across the entire Pilsen-Trutnov Basin Complex and are recorded as isochronous lithostratigraphic units separated by basin-wide hiatuses.

- Most of detected pre-Saale hiatuses have their equivalent of similar or shorter duration in NW Spain and also in some other continental basins of central Europe (e.g. Erzgebirge, Upper Silesia).

- Comparison of ages of embedded volcanic rocks with existing radioisotopic ages of plutonic bodies demonstrates the relationship between plutonic and volcanic processes. 
This magmatism suggests a crucial role of mantle relaxation related to slab break-off, together with large-scale movements along a system of transverse NW and NE to NNE-striking shear/fault zones for emplacement of volcanic bodies. It also suggests that updoming of shallow plutons probably controlled the base level changes and, in turn, deposition and erosion over the entire basin complex.

\section{Acknowledgement}

The authors gratefully acknowledge the Grant Agency of the Czech Republic for its financial support of the research via the grant project P210-12-2053. Without this support this research would not be possible. This is also a contribution to the internal project Prvouk 44 of the Faculty of Science, Charles University in Prague. We also highly appreciate the comments of all the reviewers, J. Schneider (Freiberg, Germany), M. Stárková and V. Rapprich (both Czech Geological Survey, Prague). We thank also J. Zajíc (Geological Institution of the Czech Academy of Sciences, Prague), a handling editor, for his valuable comments on fauna of the studied basins. This paper is also a contribution to the aims of the Non-Marine - Marine Late Carboniferous - Permian - Early Triassic Working Group of the respective International Subcommissions on Stratigraphy of the IUGS.

\section{References}

Arthaud, F. \& Matte, P. 1977. Late Paleozoic strike-slip faulting in southern Europe and northern Africa: Result of a right-lateral shear zone between the Appalachians and the Urals. Geological Society of America Bulletin 88, 1305-1320. DOI 10.1130/0016-7606(1977)88<1305:LPSFIS >2.0.CO;2

Augustynyak, M.K. 1970. Geological atlas of the Lower Silesian Coal Basin 1:100 000. Part 2. Instytut Geologiczny, Warsawa.

Awdankiewicz, M., Awdankiewicz, H., Rapprich, V. \& STÁrKovÁ, M. 2014. A Permian andesitic tuff ring at Rožmitál (the Intra-Sudetic Basin, Czech Republic) - evolution from explosive to effusive and high-level intrusive activity. Geological Quarterly 58(4), 759-778. DOI 10.7306/gq.1184

Birgenheier, L.P., Fielding, C.R., Rygel, M.C., Frank, T.D. \& Roberts, J. 2009. Evidence for dynamic climate change on sub- $10^{6}$-years scales from the Late Paleozoic glaciation record, Tamworth Belt, New South Wales, Australia. Journal of Sedimentary Research 79, 56-82. DOI 10.2110/jsr.2009.013

Č $\mathrm{ECH}, \mathrm{S}$. (ed.) 2013. Vysvětlivky k Základní geologické mapě České republiky 1 : 25 000, 03-342 Rovensko pod Troskami. 176 pp. Česká geologická služba, Praha.

Cháb, J., Breitr, K., FatKa, O., Hladil, J., Kalvoda, J., ŠIMỦNeK, Z., ŠToRCh, P., VAŠÍČEK, Z., ZAJíc, J. \& ZAPletal, J. 2008. Stručná geologie základu Českého masivu a jeho karbonského a permského pokryvu. 283 pp. Vydavatelství České geologické služby, Praha.

СHÁB, J., STRÁníK, Z. \& Eliáš, M. 2007. Geologická mapa České republiky $1: 500$ 000. Česká geologická služba, Praha.
Cleal, C.J. 2005. The Westphalian macrofloral record from the cratonic central Pennines Basin, UK. Zeitschrift der Deutschen Gesellschaft für Geowissenschaften 156, 387-410. DOI 10.1127/1860-1804/2005/0156-0387

Cleal, C.J. 2007. The Westphalian-Stephanian macrofloral record from the South Wales Coalfield. Geological Magazine 144, 465-486. DOI 10.1017/S0016756807003305

Cleal, C.J., Opluštil, S., Thomas, B.A. \& Tenchov, Y. 2010. Late Moscovian terrestrial biotas and palaeoenvironments of Variscan Euramerica. Netherlands Journal of Geosciences 88, 181-278.

Condon, D.J., Schoene, B., McLean, N.M., Bowring, S.A. \& Parrish, R.R. 2015. Metrology and traceability of U-Pb isotope dilution geochronology (EARTHTIME Tracer Calibration Part I). Geochimica et Cosmochimica Acta 164, 464-480. DOI 10.1016/j.gca.2015.05.026

Coubal, M., Adamovič, J., Málek, J. \& Prouza, V. 2014. Architecture of thrust faults with along strike variations in fault-plane dip: anatomy of the Lusatian Fault, Bohemian Massif. Journal of Geosciences 59(3), 183-208.

DOI 10.3190/jgeosci.174

Davydov, V.I., Crowley, J.L., Schmitz, M.D. \& Poletaev, V.I. 2010. High-precision U-Pb zircon age calibration of the global Carboniferous time scale and Milankovitch band cyclicity in the Donets Basin, eastern Ukraine. Geochemistry, Geophysics, Geosystems 11(1), 1-22.

DiMichele, W.A. 2014. Wetland-Dryland Vegetational Dynamics in the Pennsylvanian Ice Age Tropics. International Journal of Plant Sciences 175(2), 123-164. DOI 10.1086/675235

DiMichele, W.A., Cecil, B.C., Montañez, I.P. \& Falcon-Lang, H.J. 2010. Cyclic changes in Pennsylvanian paleoclimate and effects on floristic dynamics in tropical Pangaea. International Journal of Coal Geology 83, 329-344.

DOI 10.1016/j.coal.2010.01.007

Eros, J.M., Montañez, I.P., Osleger, D.A., Davydov, V.I., Nemyrovska, T.I., Poletaev, V.I. \& Zhykalyak, M.V. 2012. Sequence stratigraphy and onlap history of the Donets Basin, Ukraine: insight into Carboniferous icehouse dynamics. Palaeogeography, Palaeoclimatology, Palaeoecology 313-314, 1-25. DOI 10.1016/j.palaeo.2011.08.019

Fediuk, F. 2001. Spodnoautunské vulkanity Kozákova, severní Čechy. Zprávy o geologických výzkumech v roce 2000, 27-30.

Fielding, C.R., FranK, T.D. \& Isbell, J.L. 2008. The Late Paleozoic ice age - A review of current understanding and synthesis of global climate patterns, 343-354. In FiELDING, C.R., FRANK, T.D. \& IsBell, J.L. (eds) Resolving the Late Paleozoic Ice Age in time and Space. Geological Society of America, Special Papers 441 .

Franke, W. 2000. The mid-European segment of the Variscides: tectonostratigraphic units, terrane boundaries and plate tectonic evolution. Geological Society of London, Special Publication 179, 35-61. DOI 10.1144/GSL.SP.2000.179.01.05

Gradstein, F.M., OGG, J.G., Schmitz, M.D. \& OGG, G.M. 2012. The Geological Time Scale 2012. 1129 pp. Elsevier.

Havlena, V. 1956. Cyclical sedimentation in the Žaclér beds. Rozpravy Československé akademie věd, řada matematicko-přirodních věd 66(5), 1-57. [n Czech with English abstract]

Havlena, V. 1957. Rozčlenění uhelných slojí a tak zvaných hořlavých břidlic v severní části permokarbonského synklinoria 
v Podkrkonoší. Časopis pro mineralogii a geologii 2, 240-253.

Havlena, V. 1964. Geologie uhelných ložisek 2. 437 pp. Nakladatelství Československé akademie věd, Praha.

Havlena, V. \& PešEK, J. 1980. Stratigrafie, paleogeografie a základní strukturní členění limnického permokarbonu Čech a Moravy. Sborník Západočeského muzea v Plzni, Příroda 34, $1-144$.

HeCKel, P.H. 2002. Genetic stratigraphy and conodont biostratigraphy of upper Desmoinesian-Missourian (Pennsylvanian) cyclothem succession in Midcontinent North America, 99-119. In Hills, L.V., Henderson, C.M. \& Bamber, E.W. (eds) The Carboniferous and Permian of the World. Canadian Society of Petroleum Geologists Memoir 19.

Heckel, P.H. 2008. Pennsylvanian cyclothems in Midcontinent North America as far-field effect of waxing and waning of Gondwana ice sheets, 275-289. In FIELDING, C.R., Frank, T.D. \& IsBeLl, J.L. (eds) Resolving the Late Paleozoic Ice Age in time and Space. Geological Society of America, Special Papers 441.

Heckel, P.H., Alekseev, A.S., Barrick, J.E., Boardman, D.R., Goreva, N.V., Nemyrovska, T.I., Ueno, K., Villa, E. \& WORK, D.M. 2007. Cyclothem ("digital") correlation and biostratigraphy across the global Moscovian-KasimovianGzhelian Stage boundary interval (Middle-Upper Pennsylvanian) in North America and Eastern Europe. Geology 35, 607-610. DOI 10.1130/G23564A.1

Hoffmann, U., Breitkreuz, C., Breiter, K., Sergeev, S., Stanek, K. \& Tichomirova, M. 2013. Carboniferous-Permian volcanic evolution in Central Europe-U/Pb ages of volcanic rocks in Saxony (Germany) and northern Bohemia (Czech Republic). International Journal of Earth Sciences 102(1), 73-99. DOI 10.1007/s00531-012-0791-2

Hoffmann, M., Linnemann, U., Gerdes, A., Ullrich, B. \& SCHAUER, M. 2009. Timing of dextral strike-slip processes and basement exhumation in the Elbe Zone (Saxo-Thuringian Zone); the final pulse of the Variscan Orogeny in the Bohemian Massif constrained by LA-SF-ICP-MS U-Pb zircon data. Geological Society of London, Special Publications 327, 197-214. DOI 10.1144/SP327.10

Holub, V. 1961. Karbonský vulkanismus v české části vnitrosudetské deprese. Acta Musei reginaehradecensis, Série A scientiae naturales $3,1-2$.

Jaffey, A.H., Flynn, K.F., Glendenin, L.E., Bentley, W.T. \& EssLING, A.M. 1971. Precision measurement of half-lives and specific activities of U 235 and U 238. Physical Review C 4, 1889. DOI 10.1103/PhysRevC.4.1889

KAISER, T. 1959. Předběžná zpráva o geologickém výzkumu v žacléřské oblasti. Zprávy o geologických výzkumech v roce 1957, 88-90.

KeRP, J.H.F. 1988. Aspects of Permian palaeobotany and palynology. X. The West- and Central European species of the genus Autunia Krasser emend. Kerp (Peltaspermaceae) and the form-genus Rhachiphyllum Kerp (callipterid foliage). Review of Palaeobotany and Palynology 54, 249-360. DOI 10.1016/0034-6667(88)90017-6

Kovařííová, P., Siebel, W., JelíneK, E., ŠTemprok, M., Kachlí, V., Holub, F.V. \& Blecha, V. 2007. Petrology, geochemistry and zircon age for redwitzite at Abertamy, NW Bohemian
Massif (Czech Republic): tracing the mantle component in Late Variscan intrusions. Chemie der Erde, Geochemistry 67(2), 151-174. DOI 10.1016/j.chemer.2007.04.002

Kozlowski, S. 1963. Geologia wulkanitów permskich w centralnej częsci niecki śródsudeckiej. Prace geologiczne Komisji Nauk Geologicznych PAN Kraków 14, 1-84.

Kroner, U. \& Romer, R.L. 2013. Two plates - Many subduction zones: The Variscan orogeny reconsidered. Gondwana Research 24, 298-329.

KryZa, R. \& Awdankiewicz, M. 2012. Ambiguous geological position of Carboniferous rhyodacites in the Intra-Sudetic Ba$\sin$ (SW Poland) clarified by SHRIMP zircon ages. Geological Quarterly 56(1), 55-65.

Kryza, R., Schaltegger, U., Oberc-Dziedzic, T., Pin, C. \& Ovtcharova, M. 2014. Geochronology of a composite granitoid pluton: a high-precision ID-TIMS U-Pb zircon study of the Variscan Karkonosze Granite (SW Poland). International Journal of Earth Sciences 103(3), 683-696.

DOI 10.1007/s00531-013-0995-0

Kusiak, M.A., Williams, I.S., Dunkley, D.J., KoneČnÝ, P., SlabÝ, E. \& Martin, H. 2014. Monazite to the rescue: $\mathrm{U}-\mathrm{Th}-\mathrm{Pb}$ dating of the intrusive history of the composite Karkonosze pluton, Bohemian Massif. Chemical Geology 364, 76-92. DOI 10.1016/j.chemgeo.2013.11.016

KuŽvart, M. \& SuK, M. 1957. Paleovulkanické pozorování na spodnopermských výlevných porfyrech Vraních hor v severovýchodních Čechách. Věstník Ústředního ústavu geologického 32, 333-338.

Laurent, A., Janoušek, V., Magna, T., Schulmann, K. \& Míková, J. 2014. Petrogenesis and geochronology of a postorogenic calc-alkaline magmatic association: the Žulová Pluton, Bohemian Massif. Journal of Geosciences 59(4), 415-440. DOI 10.3190/jgeosci.176

Linnemann, U. \& Schauer, M. 1999. Die Entstehung der Elbezone vor dem Hintergrund der cadomischen und variszischen Geschichte des Saxothuringischen Terranes; Konsequenzen aus einer abgedeckten geologischen Karte. Zeitschrift für Geologische Wissenschaften 27, 5-6.

Lippolt, H.J., Hess, J.C., Holub, V.M. \& PešEK, J. 1986. Correlation of the Upper Carboniferous Deposits in the Bohemian Massif (Czechoslovakia) and in the Ruhr District (FR Germany). Evidence from ${ }^{40} \mathrm{Ar} /{ }^{39} \mathrm{Ar}$ Ages of Tuff Layers. Zeitschrift der Deutschen geologischen Gesellschaft 137, 447-464.

Lucas, S.G., Allen, B.D., Krainer, K., Barrick, J., Vachard, D., Schneider, J.W., DiMichele, W.A. \& Bashforth, A.R. 2011. Precise age and biostratigraphic significance of the Kinney Brick Quarry Lagerstätte, Pennsylvanian of New Mexico, USA. Stratigraphy 8(1), 7-27.

Machowiak, K., Muszynski, A. \& Armstrong, R. 2004. High-level volcanic-granodioritic intrusions from Zelezniak Hill; Kaczawa Mountains, Sudetes, SW Poland. Geological Society Special Publications 234, 67-74. DOI 10.1144/GSL.SP.2004.234.01.06

Marheine, D., Kachlík, V., Maluski, H., PatočKa, F. \& Zelazniewicz, A. 2002. The Ar-Ar ages from the West Sudetes (NE Bohemian Massif): constraints on the Variscan polyphase tectonothermal development. Geological Society of London, Special Publications 201, 133-155.

DOI 10.1144/GSL.SP.2002.201.01.07 
Matte, P. 2001. The Variscan collage and orogeny (480-290 Ma) and the tectonic definition of the Armorica microplate: a review. Terra Nova 13, 122-128. DOI 10.1046/j.1365-3121.2001.00327.x

Mclean, N.M., Condon, D.J., Schoene, B. \& Bowring, S.A. 2015. Evaluating uncertainties in the calibration of isotopic reference materials and multi-element isotopic tracers (EARTHTIME Tracer Calibration Part II). Geochimica et Cosmochimica Acta 164, 481-501.

DOI 10.1016/j.gca.2015.02.040

Mencl, V., Matysová, P. \& Sakala, J. 2009. Silicified woods from the Czech part of the Intra Sudetic Basin (Late Pennsylvanian, Bohemian Massif, Czech Republic): systematics, silicification and palaeoenvironment. Neues Jahrbuch für Geologie und Paläontologie, Abhandlungen 252(3), 269-288. DOI 10.1127/0077-7749/2009/0252-0269

Michel, L.A., Tabor, N.J., Montañez, I.P., Schmitz, M.D. \& DAvydov, V.I. 2015. Chronostratigraphy and paleoclimatology of the Lodève Basin, France: Evidence for a pan-tropical aridification event across the Carboniferous-Permian boundary. Palaeogeography, Palaeoclimatology, Palaeoecology 430, 118-131. DOI 10.1016/j.palaeo.2015.03.020

NĚMEJC, F. 1953. Úvod do floristické stratigrafie kamenouhelných oblastí ČSR. 173 pp. Academia, Praha.

NĚMEJC, F. 1958. Biostratigraphical studies in the Carboniferous of the Bohemian part of the Intrasudetic Basin. Rozpravy Československé akademie věd, $\breve{R} a d a$ matematických a př́rodnich věd 68(6), 1-67.

Oberc-Dziedzic, T., Kryza, R., Pin, C. \& Madej, S. 2013. Variscan granitoid plutonism in the Strzelin Massif (SW Poland): petrology and age of the composite Strzelin granite intrusion. Geological Quarterly 57(2), 269-288. DOI $10.7306 /$ gq. 1083

Opluštil, S. 2003. Sedimentation and paleogeography of the Radnice Member (Duckmantian/Bolsovian) in the Kladno part of the Kladno-Rakovník Basin. Sborník Západočeského muzea v Plzni, Príroda 102, 1-83.

OpLušTIL, S. 2005a. Evolution of the Middle Westphalian river valley drainage system in central Bohemia (Czech Republic) and its palaeogeographic implication. Palaeogeography, Palaeoclimatology, Palaeoecology 222, 223-258. DOI 10.1016/j.palaeo.2005.03.016

OpLuŠTIL, S. 2005b. The effect of paleotopography, tectonics and sediment supply on quality of coal seams in continental basins of central and western Bohemia (Westphalian), Czech Republic. International Journal of Coal Geology 64, 173-203. DOI 10.1016/j.coal.2005.03.022

Opluštil, S., EdREss, N.A. \& SÝKOROvÁ, I. 2013b. Climatic vs. tectonic controls on peat accretion in non-marine setting; an example from the Žaclér Formation (Yeadonian-Bolsovian) in the Intra-Sudetic Basin (Czech Republic). International Journal of Coal Geology 116-117, 135-157. DOI 10.1016/j.coal.2013.07.011

Opluštil, S., LojKA, R., Rosenau, N.A., STRnAD, L. \& SÝKorovÁ, I. 2015. Middle Moscovian climate of eastern equatorial Pangea recorded in paleosols and fluvial architecture. Palaeogeography, Palaeoclimatology, Palaeoecology 440, 328-352. DOI 10.1016/j.palaeo.2015.09.009

OpluštiL, S. \& PEŠEK, J. 1998. Stratigraphy, palaeoclimatology and palaeogeography of the Late Palaeozoic continental deposits in the Czech Republic, 597-620. In Crasquin-Soleau, S., Izart, A., Vaslet, D. \& DeWever, P. (eds) Peri-Tethys Stratigraphic Correlations 2. Geodiversitas 20(4).

Opluštil, S., PŠEničKa, J., Libertín, M. \& ŠImŮneK, Z. 2007. Vegetation patterns of Westphalian and Lower Stephanian mire assemblages preserved in tuff beds of the continental basins of Czech Republic. Review of Palaeobotany and Palynology 143, 107-154.

DOI 10.1016/j.revpalbo.2006.06.004

Opluštil, S., Schmitz, M., Cleal, C.J. \& Martínek, K. 2016. A review of the Middle-Late Pennsylvanian west European regional substages and floral biozones, and their correlation to the Global Time Scale based on new U-Pb ages. Earth Science Reviews 154, 301-335.

DOI 10.1016/j.earscirev.2016.01.004

Opluštil, S., ŠimưNeK, Z., Zajíc, J. \& Mencl, V. 2013a. Climatic and biotic changes around the Carboniferous/Permian boundary recorded in the continental basins of the Czech Republic. International Journal of Coal Geology 119, 114-151.

DOI 10.1016/j.coal.2013.07.014

Owens, B., Riley, N.J. \& Calver, M.A. 1985. Boundary stratotypes and new stage names for the Lower and Middle Westphalian sequences in Britain. Compte Rendu 10e Congrès International de Stratigraphie et de Géologie du Carbonifère (Madrid 1983) 4, 461-472.

PEŠEK, J. 1994. Carboniferous of central and western Bohemia (Czech Republic). 60 pp. Czech Geological Survey, Prague.

PEŠEK, J. 2004. Late Palaeozoic limnic basis and coal deposits of the Czech Republic. Folia Musei rerum naturalium Bohemiae occidentalis, Geologica 1, 1-188.

Pešek, J., Holub, V., Jaroš, J., Malý, L., Martínek, K., Prouza, V., Spudil, J. \& TÁsler, R. 2001. Geologie a ložiska svrchnopaleozoických limnických pánví České republiky. 243 pp. Český geologický ústav, Praha.

Pešek, J., Opluštil, S., Kumpera, O., Holub, V., SkočEK, V. Dvořák, J., Prouza, V. \& Tásler, R. 1998. Paleogeographic Atlas, Late Paleozoic and Triassic Formations, Czech Republic. 56 pp. Czech Geological Survey, Prague.

PeŠEK, J. \& SÝKOROVÁ, I. 2006. A review of the timing of coalification in the light of coal seam erosion, clastic dykes and coal clasts. International Journal of Coal Geology 66, 13-34. DOI 10.1016/j.coal.2005.05.010

Pointon, M.A., Chew, D.M., Ovtcharova, M., Sevastopulo, G.D. \& CRowley, Q.G. 2012. New high-precision U-Pb dates from western European Carboniferous tuffs; implications for time scale calibration, the periodicity of late Carboniferous cycles and stratigraphical correlation. Journal of the Geological Society, London 169, 713-721. DOI 10.1144/jgs2011-092

Prouza, V. \& Tásler, R. 1985. Přehledná geologická mapa podkrkonošské pánve. Ústřední ústav geologický, Praha.

PuRKYŇOvÁ, E. 1986. Floristická zonálnost žacléřského souvrství v důlním poli Dolu Šverma u Žaclére (vnitrosudetská pánev). Časopis Slezského muzea, Série A - vědy př́rodní 35, 57-63.

RAPPRich, V. 2010. Vulkanismus, 36-42. In ProuZA, V. (ed.) Vysvětlivky k základní geologické mapě $1: 25$ 000, 03-413 Semily. Česká geologická služba, Praha.

RIEGER, Z. 1968. Fytopaleontologicko-stratigrafický výzkum 
stephanu a autunu podkrkonošské pánve. Věstník Ústředního ústavu geologického 43, 449-457.

Rößler, R., Zierold, T., Feng, Z., Kretzschmar, R., Merbitz, M., Annacker, V. \& Schneider, J.W. 2012. A snapshot of an Early Permian ecosystem preserved by explosive volcanism: new results from the petrified forest of Chemnitz, Germany. Palaois 27, 814-834. DOI 10.2110/palo.2011.p11-112r

Scheck, M., Bayer, U., Otto, V., Lamarche, J., Banka, D. \& Pharaoh, T. 2002. The Elbe fault system in North Central Europe; a basement controlled zone of crustal weakness. Tectonophysics 360, 1-4. DOI 10.1016/S0040-1951(02)00357-8

Schmitz, M.D. \& DAvydov, V.I. 2012. Quantitative radiometric and biostratigraphic calibration of the global Pennsylvanian Early Permian time scale. Geological Society of America Bulletin 124, 549-577. DOI 10.1130/B30385.1

Schmitz, M.D. \& Schoene, B. 2007. Derivation of isotope ratios, errors, and error correlations for U-Pb geochronology using ${ }^{205} \mathrm{~Pb}-{ }^{235} \mathrm{U}-\left({ }^{233} \mathrm{U}\right)$-spiked isotope dilution thermal ionization mass spectrometric data. Geochemistry, Geophysics, Geosystems 8, 1-20. DOI 10.1029/2006GC001492

SCHNEIDER, J.W. 1996. Xenacanth teeth: a key for taxonomy and biostratigraphy. Modern Geology 20, 321-340.

Schneider, J.W., Lucas, S.G., Barrick, J., Werneburg, R., Shcherbakov, D.E., Silantiev, V., Shen, S., Saber, H., Belahmira, A., Scholze, F. \& Rößler, R. 2014. Carboniferous and Permian nonmarine-marine correlation - methods, results, future tasks, 73-77. In Nurgaliev, D.K. (ed.) Kazan Golovkinsky Stratigraphic Meeting: Carboniferous and Permian Earth systems, stratigraphic events, biotic evolution, sedimentary basins and resources, Abstract volume.

Schneider, J.W. \& Werneburg, R. 2012. Stratigraphie des Rotliegend mit Insekten und Amphibien; in Deutsche Stratigraphische Komission, Stratigraphie von Deutschland $\mathrm{X}$. Rotliegend. Teil I: Innervariscische Becken. Schriftenreihe der Deutschen Gesellschaft für Geowissenschaften 61, $110-142$.

Schneider, J., Werneburg, R., Lucas, S.G., Barrick, J., SAber, H. \& FisCHER, J. 2013. Nonmarine-marine correlation of European and North American Late Carboniferous and Early Permian deposits, 372. In LuCAS, S.G., DiMichele, W.A., BARRICK, J.E., Schneider, J.W. \& Spielmann, J.A. (eds) The Carboniferous-Permian Transition. New Mexico Museum of Natural History and Science Bulletin 60.

Schneider, J.W., Werneburg, R., Rößler, R., Voigt, S. \& Scholze, F. 2015. Example for the description of basins in the CPT Nonmarine-Marine Correlation Chart: Thuringian Forest Basin, East Germany. Permophiles 61, 29-35.

Schneider, J. \& Zajíc, J. 1994. Xenacanthiden (Pisces, Chondrichthyes) des mitteleuropäischen Oberkarbon und Perm Revision der Originale zu Goldfuss 1847, Beyrich 1848, Kner 1867 und Fritsch 1879-1890. Freiberger Forschungshefte, Reihe C 452, 101-151.

SCHOVÁNKOVÁ, D. 1985. Mladopaleozoický vulkanismus mnichovohradištské a podkrkonošské pánve. MS Český geologický ústav, Praha.

Schulmann, K., Martínez Catalán, J.R., Lardeaux, J.M., JANOUŠEK, V. \& OGgiAno, G. 2014. The Variscan orogeny: extent, timescale and the formation of the European crust, 1-6. In
Schulmann, K., Martínez Catalán, J.R., Lardeaux, J.M., JANOUŠEK, V. \& OGGIANO, G. (eds) The Variscan orogeny: extent, timescale and the formation of the European crust. Geological Society of London, Special Publications 405.

ŠETLíK, J. 1977. Results on recent investigation on the Carboniferous flora of Bohemia, 315-340. In Holub, V. \& WAGNER, R.H. (eds) Symposium on Carboniferous Stratigraphy. Czechoslovakian Geological Survey, Prague.

Sкос̌Ек, V. 1990. Stephanian lacustrine-deltaic sequence in central and northeast Bohemia. Sborník geologických věd, Geologie 45, 91-122.

Sкос̌EK, V. \& Holub, V. 1968. Origin, age and characteristics of fossil Late Palaeozoic weathering residues in the Bohemian Massif. Sborník geologických věd, R̆ada G - Geologie 14, 3-46.

Skopec, J., Kobr, M. \& PeŠEK, J. 2001. Carboniferous river valleys identified in the Mšeno-Roudnice Basin in the Slaný and Líně formations (Stephanian B and C) in central Bohemia and their manifestations in geophysical methods. Acta Universitatis Carolinae, Geologica 45(2-4), 117-123.

SKopeC, J. \& PeŠEK, J. 2005. Anomalous dips of some Upper Carboniferous strata in the Mšeno-Roudnice Basin based on borehole data and reflection seismic measurements. Bulletin of Geosciences 80, 85-92.

Spudil, J. 1999. Group of Seams of the Jan Šverma Mine at Žaclér (Intra-Sudetic Basin). Acta Universitatis Carolinae, Geologica 43(4), 589-598.

ŠTAmberg, S. 2013. Knowledge of the Carboniferous and Permian actinopterygian fishes of the Bohemian Massif - 100 years after Antonín Frič. Sborník Národního muzea v Praze, R̆ada Bpřirodní vědy 69(3-4), 159-181.

S̆TAMBERG, S. 2014. Fossiliferous Early Permian horizons of the Krkonoše Piedmont Basin and the Boskovice Graben (Bohemian Massif) in view of the occurrence of actinopterygians. Paläontologie, Stratigraphie, Fazies 22, Freiberger Forschungshefte, Reihe C 548, 45-60.

Štamberg, S. \& Zajíc, J. 2008. Carboniferous and Permian faunas and their occurence in the limnic basins of the Czech Republic. 224 pp. Museum of Eastern Bohemia at Hradec Králové.

Stárková, M., Rapprich, V. \& Breitkreuz, C. 2011. Variable eruptive styles in an ancient monogenetic volcanic field: examples from the Permian Levin Volcanic Field (Krkonose Piedmont Basin, Bohemian Massif). Journal of Geosciences 56(2), 163-180.

Stille, H. 1920. Alter und Art der Phasen variscischer Gebirgsbildung. Nachrichten von der Gesellschaft der Wissenschaften zu Göttingen, Mathematisch-Physikalische Klasse, 218-224.

StUR, D. 1885-1887. Die Karbonflora der Schatzlarer Schichten. Abhandlundgen der Kaiserlich-königlichen geologischen Reichsanstalt 11.

STŘEDA, J. 1972. Závěrečná zpráva úkolu Křenov-5120331391. Surovina kámen. MS Archive Geofond, Praha.

TÁsler, R., Čadková, Z., Dvoř́á, J., Fediuk, F., Chaloupský, J., Jetel, J., Kaiserová-Kalibová, M., Prouza, V., SchovánKovÁ-HrdličKová, D., STŘEdA, J., STŘídA, M. \& ŠEtLík, J. 1979. Geology of the Bohemian part of the Intra-Sudetic Basin. 296 pp. Academia, Praha. [in Czech with English summary] 
Tásler, R., Havlena, V. \& Prouza, V. 1981. Nové litostratigrafické členění centrální a západní části podkrkonošské pánve. Věstník Ústředního ústavu geologického 56(3), $129-142$.

TÁsler, R. \& Prouza, V. 1980. Přehledná geologická mapa broumovského výběžku. Ústřední ústav geologický, Praha.

Thompson, R.N. 1982. Magmatism of the British tertiary Volcanic Province. Scottish Journal of Geology 18, 49-107. DOI 10.1144/sjg18010049

Timmerman, M.J. 2004. Timing, geodynamic setting and character of Permo-Carboniferous magmatism in the foreland of the Variscan Orogen, NW Europe, 41-74. In Wilson, M., Neumann, E.R., Davies, G.R., Timmerman, M., Heeremans, J. \& Larsen, B.T. (eds) Permo-Carboniferous Magmatism and Rifting in Europe. Geological Society of London, Special Publications 223.

Turek, V., Mikuláš, R., Libertín, M. \& JiráseK, J. 2008. Trace fossils from the Upper Carboniferous fluvial sediments of the Intra-Sudetic Basin, Czech Republic, 47-49. In ŠTAMBERG, S. \& ZAJíc, J. (eds) Faunas and palaeoenvironments of the Late Palaeozoic. Special Publication to $5^{\text {th }}$ Symposium on Permo-Carboniferous Faunas. Museum of Eastern Bohemia at Hradec Králové.

Turnau, E., Żelaźniewicz, A. \& Franke, W. 2002. Middle to early late Viséan onset of late orogenic sedimentation in the Intra-Sudetic Basin, West Sudetes: miospore evidence and tectonic implication. Geologia Sudetica 34, 9-16.

TurniaK, K. \& BröcKer, M. 2002. Age of the two-mica granite from the Strzegom-Sobotka Massif; new data from $\mathrm{U} / \mathrm{Pb}$ monazite and xenotime study. Prace Specjalne Polskie Towarzystwo Mineralogiczne 20, 211-213.

Ulrych, J., Fediuk, F., Lang, M. \& Martinec, P. 2004. Late Paleozoic volcanic rocks of the Intra-Sudetic Basin, Bohemian Massif: petrological and geochemical characteristics. Chemie der Erde, Geochemistry 64(2), 127-153. DOI 10.1016/j.chemer.2003.11.002

Ulrych, J., Pešek, J., Štěránková-Svobodová, J., Bosák, P., Loyd, F.E., Von Seckendorf, V., Lang, M. \& Novák, J.K. 2006. Permo-Carboniferous volcanism in late Variscan continental basins of the Bohemian Massif (Czech Republic): geochemical characteristic. Chemie der Erde, Geochemistry 66(1), 37-56. DOI 10.1016/j.chemer.2004.02.001

VALín, F. 1963. Petrografie některých proplástků (tzv. „tonsteinů“) kamenouhelných slojí ve stefanu vnitrosudetské deprese (Hronov, Radvanice). Věstník Ústředního ústavu geologického 27, 409-444.

WAGNER, R.H. 1977. Comments on the upper Westphalian and Stephanian floras of Czechoslovakia, with particular reference to their stratigraphic age, 441-457. In HoLuB, V.M. \& WAGNER, R.H. (eds) Symposium on Carboniferous Stratigraphy. Geological Survey, Prague.

Wagner, R.H. 1984. Megafloral zones of the Carboniferous.
Compte Rendu 9 e Congrès International de Stratigraphie et de Géologie du Carbonifère (Washington, 1979) 2, 109-134.

Wagner, R.H. \& Álvarez-VÁzquez, C. 2010. The Carboniferous floras of the Iberian Peninsula: a synthesis with geological connotations. Review of Palaeobotany and Palynology 162, 239-324. DOI 10.1016/j.revpalbo.2010.06.005

WAgner, R.H., PARK, R.K., WinkLER Prins, C.F. \& Lys, M. 1977. The Post-Leonian Basin in Palencia: A report on the Stratotype of the Cantabrian Stage, 89-146. In Holub, V.M. \& Wagner, R.H. (eds) Symposium on Carboniferous Stratigraphy. Geological Survey, Prague.

Wenzel, T., Hengst, M. \& Pilot, J. 1993. The plutonic rocks of the Elbe Valley-zone (Germany); evidence for the magmatic development from single-zircon evaporation and K-Ar age determinations. Chemical Geology 104, 1-4. DOI 10.1016/0009-2541(93)90143-7

Werneburg, R. \& Schneider, J.W. 2006. Amphibian biostratigraphy of the European Permo-Carboniferous, 201-215. In LuCAs, S.G., CAssinis, G. \& SCHNeIder, J.W. (eds) Non-marine Permian Biostratigraphy and Biochronology. Geological Society of London, Special Publication 265.

Winchester, J.A. and Team 2002. Palaeozoic amalgamation of Central Europe: new results from recent geological and geophysical investigations. Tectonophysics 360, 5-21. DOI 10.1016/S0040-1951(02)00344-X

ZAJíc, J. 2000. Vertebrate zonation of the non-marine Upper Carboniferous - Lower Permian basins of the Czech Republic. Courier Forschunginstitut Senckenberg 223, 563-575.

ZAJíc, J. 2007. Carboniferous fauna of the Krkonoše Piedmont Basin. Acta Musei reginaehradecensis, Série A - scientiae naturales 32, 11-16.

Zajíc, J. 2014. Permian fauna of the Krkonoše Piedmont Basin (Bohemian Massif, Central Europe). Sborník Národního muzea v Praze, Řada B - př́rodní vědy 70(3-4), 131-142.

ŽÁk, J., Verner, K., JANOUŠEK, V., Holub, F.V., KAChlík, V., Finger, F., Hajná, J., Tomek, F., Vondrovic, L. \& Trubač, J. 2014. A plate-kinematic model for the assembly of the Bohemian Massif constrained by structural relationships around granitoid plutons, 169-196. In Schulmann, K., MartíneZ Catalán, J.R., Lardeaux, J.M., Janoušek, V. \& Oggiano, G. (eds) The Variscan Orogeny: Extent, Timescale and the Formation of the European Crust. Geological Society of London, Special Publications 405.

ŽÁk, J., Verner, K., Sláma, J., Kachlík, V. \& Chlupáčová, M. 2013. Multistage magma emplacement and progressive strain accumulation in the shallow-level Krkonose-Jizera plutonic complex, Bohemian Massif. Tectonics 32(5), 1493-1512. DOI 10.1002/tect.20088

Zdanowski, A. \& Żakowa, H. 1995. The Carboniferous System in Poland. Prace Panstwowego Instytutu Geologicznego 148, $1-215$. 